\title{
Biogeochemistry of a deep-sea whale fall: sulfate reduction, sulfide efflux and methanogenesis
}

\author{
Tina Treude ${ }^{1,5, *}$, Craig R. Smith ${ }^{2}$, Frank Wenzhöfer ${ }^{1,3}$, Erin Carney ${ }^{1,6}$, \\ Angelo F. Bernardino ${ }^{2,4}$, Angelos K. Hannides ${ }^{2,7}$, Martin Krüger ${ }^{1,8}$, Antje Boetius ${ }^{1,3}$ \\ ${ }^{1}$ Max Planck Institute for Marine Microbiology, Department of Biogeochemistry, Celsiusstrasse 1, 28359 Bremen, Germany \\ ${ }^{2}$ University of Hawaii at Manoa, Department of Oceanography, 1000 Pope Road, Honolulu, Hawaii 96822, USA \\ ${ }^{3}$ Alfred Wegener Institute for Polar and Marine Research, HGF MPG Research Group on Deep Sea Ecology and Technolgy, \\ 27515 Bremerhaven, Germany \\ ${ }^{4}$ Oceanographic Institute, University of São Paulo, Praça do Oceanográfico, 191, 05508-120 São Paulo, Brazil \\ ${ }^{5}$ Present address: Leibniz Institute of Marine Sciences, IFM-GEOMAR, Wischhofstr. 1-3, 24148 Kiel, Germany \\ ${ }^{6}$ Present address: New York Methodist Hospital, Department of Medicine, 506 6th Street, Brooklyn, New York 11215, USA \\ ${ }^{7}$ Present address: Department of Fisheries and Marine Research, 101 Bethlehem Street, 1416 Nicosia, Cyprus \\ ${ }^{8}$ Present address: Bundesanstalt für Geowissenschaften und Rohstoffe, Stilleweg 2, 30655 Hannover, Germany
}

\begin{abstract}
Deep-sea whale falls create sulfidic habitats supporting chemoautotrophic communities, but microbial processes underlying the formation of such habitats remain poorly evaluated. Microbial degradation processes (sulfate reduction, methanogenesis) and biogeochemical gradients were studied in a whale-fall habitat created by a $30 \mathrm{t}$ whale carcass deployed at $1675 \mathrm{~m}$ depth for 6 to $7 \mathrm{yr}$ on the California margin. A variety of measurements were conducted including photomosaicking, microsensor measurements, radiotracer incubations and geochemical analyses. Sediments were studied at different distances (0 to $9 \mathrm{~m}$ ) from the whale fall. Highest microbial activities and steepest vertical geochemical gradients were found within $0.5 \mathrm{~m}$ of the whale fall, revealing ex situ sulfate reduction and in vitro methanogenesis rates of up to 717 and $99 \mathrm{mmol} \mathrm{m}^{-2} \mathrm{~d}^{-1}$, respectively. In sediments containing whale biomass, methanogenesis was equivalent to 20 to $30 \%$ of sulfate reduction. During in vitro sediment studies, sulfide and methane were produced within days to weeks after addition of whale biomass, indicating that chemosynthesis is promoted at early stages of the whale fall. Total sulfide production from sediments within $0.5 \mathrm{~m}$ of the whale fall was $2.1 \pm 3$ and $1.5 \pm 2.1 \mathrm{~mol} \mathrm{~d}^{-1}$ in Years 6 and 7, respectively, of which $\sim 200 \mathrm{mmol} \mathrm{d}^{-1}$ were available as free sulfide. Sulfate reduction in bones was much lower, accounting for a total availability of $\sim 10 \mathrm{mmol}$ sulfide $\mathrm{d}^{-1}$. Over periods of at least $7 \mathrm{yr}$, whale falls can create sulfidic conditions similar to other chemosynthetic habitats such as cold seeps and hydrothermal vents.
\end{abstract}

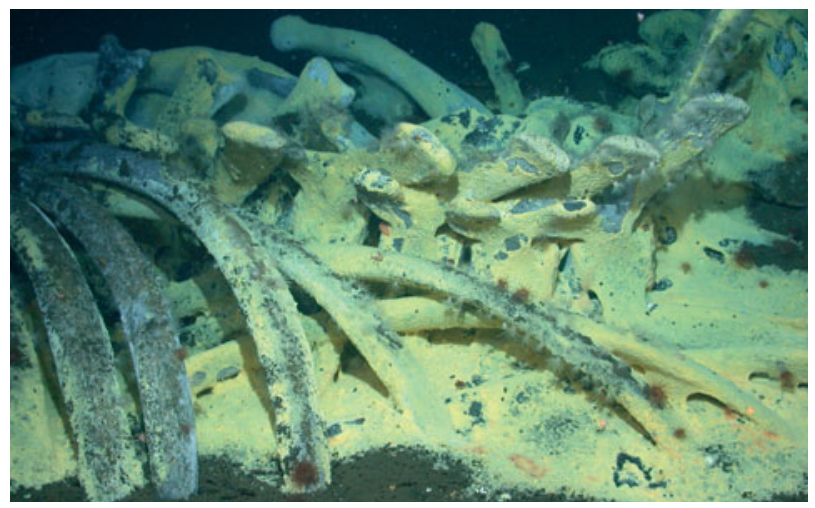

Skeleton of a whale on the deep-sea floor, covered by chemoautotrophic bacterial mats, anemones, and bone-eating worms Osedax spp., 6 yr after arrival at the seafloor.

Photo: C. R. Smith

KEY WORDS: Chemosynthesis · Organic carbon input · Microbial degradation · Sediment - Bone - Cold seep · Hydrothermal vent

\section{Resale or republication not permitted without} written consent of the publisher

\section{INTRODUCTION}

Large cetaceans suffering natural death typically sink to the seafloor (Smith 2006). In coastal waters, carcasses may refloat from decompositional gases (Allison et al. 1991) and be devoured by pelagic scavengers 
(Smith 2006). In the deep sea, cold temperatures retard decomposition and high hydrostatic pressures increase gas solubility (Allison et al. 1991), allowing whale falls to remain as food bonanzas on the deep-sea floor. Although large whale falls comprise only $\sim 0.1 \%$ of the global background particulate organic carbon (POC) flux, locally they provide an amount of organic carbon equivalent to $2000 \mathrm{yr}$ of POC flux to the deep-sea floor (Smith 2006). When deposited, large whale carcasses pass through up to 4 stages of utilization by the deepsea community (Smith et al. 1998, 2002, Smith \& Baco 2003): (1) a mobile scavenger stage, wherein scavengers such as hagfishes, sleeper sharks and amphipods feed on whale soft tissue; (2) an enrichmentopportunistic stage, where remains of the whale dispersed over the surrounding sediment are utilized by an opportunistic community with high population densities but low species richness; (3) a sulfophilic stage, where microbial consumption of organic compounds in the lipid-rich bones as well as in the organically enriched sediment sustains the production of hydrogen sulfide, which is then utilized by a chemosynthetic community; and (4) a reef stage, where the whale bones serve as hard substrate outcropping from the seafloor and as a refuge for a variety of deep-sea animals. Whale falls represent a unique habitat with some of the highest local species richness known from deep-sea hard substrates (Baco \& Smith 2003).

In the present study, we focus on the sulfophilic stage of whale falls. Microbial sulfate reduction (SR) during organic carbon degradation is postulated to be the key process releasing hydrogen sulfide from the lipid-rich bones, as well as from the surrounding carbon-enriched sediments. Whale bones contain up to $60 \%$ lipids by wet weight (Deming et al. 1997, Schuller et al. 2004 and references therein) and microbial decomposition of bone lipids can provide sulfide to the chemoautotrophic community for years to decades (Smith et al. 2002, Smith \& Baco 2003, Schuller et al. 2004). Sediments surrounding whale carcasses are enriched with lipids and other organic compounds derived from the carcass (Naganuma et al. 1996, Smith et al. 1998). The organic enrichment causes anoxic conditions in the sediment, due to high microbial oxygen consumption (Allison 1988, Allison et al. 1991), and favors anaerobic processes such as SR and methanogenesis (MG) (Goffredi et al. 2008)-processes which usually play a minor role in the carbon cycling of organic-poor, deep-sea sediments (Wenzhöfer \& Glud 2002 and references therein). Chemosynthetic sulfide-oxidizing microorganisms found at whale falls include free-living, mat-forming bacteria (e.g. Beggiatoa spp.) covering bones and sediment surfaces, as well as endosymbionts in bivalves and tubeworms (e.g. Smith et al. 1989, Bennett et al. 1994, Feld- man et al. 1998, Baco et al. 1999). These microorganisms are the basis for food chains based on chemosynthetic primary production at whale falls.

Activity of sulfate-reducing bacteria in the sulfophilic stage of whale falls has long been postulated without direct measurements of activity rates (e.g. Allison et al. 1991, Smith 1992, Bennett et al. 1994, Naganuma et al. 1996, Deming et al. 1997). A recent molecular study revealed that methanogenic archaea are an important part of the microbial community in sediments surrounding whale falls (Goffredi et al. 2008). Here we document the activity of both sulfate-reducing and methanogenic microorganisms in deep-sea sediments impacted by whale biomass. We found extreme biogeochemical gradients around the whale fall associated with microbial degradation processes. Finally, we extrapolate sulfide production rates in whale-fall sediments and bones to an entire whale-fall habitat to compare sulfide availability with other sulfur-based deep-sea habitats such as hydrothermal vents and cold seeps.

\section{MATERIALS AND METHODS}

\section{Study site}

Samples were collected from a whale fall in the Santa Cruz Basin, California $\left(33^{\circ} 27^{\prime} \mathrm{N}, 119^{\circ} 22^{\prime} \mathrm{W}, 1675 \mathrm{~m}\right.$ depth, bottom temperature $\sim 4^{\circ} \mathrm{C}$, bottom-water oxygen concentration $260 \mu \mathrm{M}$ ) using the remotely operated vehicle (ROV) 'Tiburon' during 2 cruises (28 Feb to 5 Mar 2004 and 26 Feb to 2 Mar 2005) aboard RV 'Western Flyer'. A mature grey whale Eschrichtius robustus carcass was deployed in 1998 and had an initial wet weight of $30 \mathrm{t}$ and a length of $12.5 \mathrm{~m}$ (Smith \& Baco 2003). Sediment samples were taken during the sulfophilic stage of the whale fall 6 and $7 \mathrm{yr}$ after deployment at distances of $9,3,1,0.5$ and $0 \mathrm{~m}$ from the whale fall (Fig. 1). In the original sampling design we had chosen the $9 \mathrm{~m}$ distance as background reference, but later analyses showed an influence of the whale fall on some parameters such as oxygen and methane even at this distance. At the stage of the whale fall investigated in the present study, soft tissue had been completely removed from the skeleton by scavengers and opportunistic fauna (Smith et al. 2002). Sloppy feeders had visibly distributed whale tissue fragments over the sediment to a distance of at least $3 \mathrm{~m}$ from the whale fall, and bioturbation processes had caused the burial of whale fat and tissue into the upper $15 \mathrm{~cm}$ of sediment. Chemosynthetic organisms such as mats of the sulfur-oxidizing bacteria Beggiatoa spp., 3 species of vescomyid clams and the mussel Idas washingtonia were found in abundance at the whale fall during sampling (P. A. Tyler et al. unpubl. data, C. R. Smith and A. Baco-Taylor unpubl. data). 

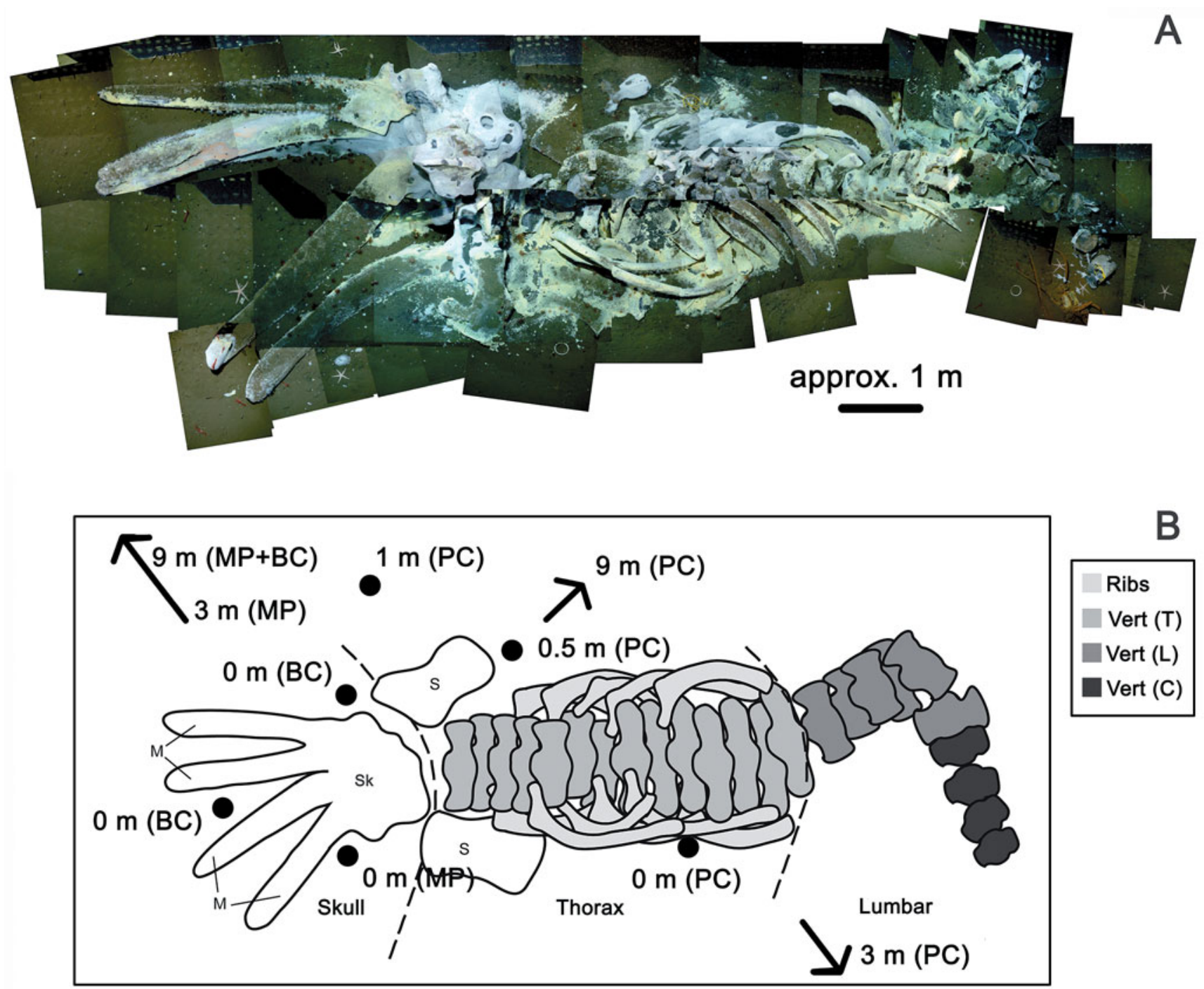

Fig. 1. (A) Photomosaic and (B) diagram of grey whale skeleton in the Santa Cruz Basin (1675 m water depth). The photomosaic is composed of single images taken in 2005 by the ROV Tiburon. Yellow spots are thick mats of filamentous sulfur bacteria. Skull (Sk), mandibles/maxillae (M), scapula (S). Positions of sediment push cores (PC), microprofiler (MP) and benthic chamber (BC) deployments at distances of 0, 0.5, 1, 3 and $9 \mathrm{~m}$ from the whale are indicated

\section{Visual estimation of high-sulfide areas}

We used the distribution of black surface sediments with and without bacterial mats, as well as bone areas covered by mats, as visual indicators of high sulfide fluxes. Blackening of sediments is caused by precipitation of metal sulfides and indicates reducing processes (Schippers \& Jørgensen 2002). Mats of giant, filamentous sulfur bacteria form where relatively high fluxes of free hydrogen sulfide reach the water-sediment interface (Sahling et al. 2002, Jørgensen \& Nelson 2004). We use the term 'black (sediment) patches' to indicate black sediment areas devoid of microbial mats, as opposed to black sediments covered by yellow/white bacterial mats. Black patches and bacterial mat (as opposed to greenish-brown, non-reduced sediment), as well as yellow/white mat-covered bone surfaces (as opposed to uncovered, brown-grayish bones) were delineated via digital color pictures. A downward looking, digital still camera mounted on the ROV was used to create photomosaics of the whale fall from ROV phototransects paralleling the long axis of the skeleton. Phototransects were conducted prior to sampling to avoid ROV disturbance of mats and sediments. During transects, ROV altitude was held constant at $\sim 2 \mathrm{~m}$ and the camera was used to obtain overlapping images. To create maps of the whale fall in 2004 and 2005, 148 and 99 selected images, respectively, were combined into a mosaic using Inkscape ${ }^{\circledR}$ and Adobe Illustrator ${ }^{\circledR}$ software. Overlapping portions of images 
were adjusted based on identifiable bone and sediment features, and images were sequentially stretched to correct for parallax. The photomosaic allowed calibration of images based on scale markers $(10 \mathrm{~cm}$ diameter white PVC rings) placed around the skeleton, using ImageJ software (NIH). Length-scale errors at the sediment-water interface are estimated to be $\leq 10 \%$.

We estimated absolute areal coverage of microbial mats and black patches at the sediment-water interface within a $50 \mathrm{~cm}$ radius of the skeleton because video surveys indicated that virtually all mats occurred within this perimeter in both 2004 and 2005. To facilitate mapping, the whale fall was divided into 3 regions: skull, thorax and lumbar (Fig. 1B). Percentage cover in photos from each region in 2004 and 2005 was estimated and then multiplied by the absolute area of each region to produce areal estimates for the entire whale fall.

Estimation of bacterial mat area on the skeleton was complicated by the protrusion of bones above the sediment-water interface and the irregular shapes of bones. Thus, we could only estimate the plan area of the total skeleton and its percentage cover by bacterial mats. To compare mat coverage of bones between 2004 and 2005, bones were grouped by type as follows: mandibles and maxillae, cranial bones (skull), scapulae, ribs, and vertebrae. Vertebrae were subsequently subdivided into thoracic, lumbar and caudal regions (Fig. 1B). Percentage of bone area covered by bacterial mat was estimated for each bone type, using individual bones within a type/region as replicates. For the number of bones analyzed (i.e. replicates) in each region, see Table 2.

\section{Sediment investigations in situ}

Microprofiler. In 2005 a new autonomous microprofiler module easily deployed by ROV (Gundersen \& Jørgensen 1990, Wenzhoefer et al. 2000) was placed at distances of 0,3 and $9 \mathrm{~m}$ from the whale fall to investigate in situ chemical pore water gradients (Fig. 1B, Table 1). At $0 \mathrm{~m}$, the instrument was placed on black sediment next to a mandible (Fig. 2). It was not possible to place the microprofiler onto microbial mat due to presence of bones. The microprofiler carried $4 \mathrm{O}_{2^{-}}$ microelectrodes (Revsbech 1989, Glud et al. 2000), 2 pH-microelectrodes (Revsbech \& Jørgensen 1986), $3 \mathrm{H}_{2} \mathrm{~S}$-microelectrodes (Jeroschewski et al. 1996), and 1 resistivity sensor used to determine the position of the sediment surface relative to the microsensors. Measurement cycles were initiated by pressing a magnetic switch, and the instrument was repeatedly repositioned by the ROV. The central cylinder was programmed to gradually move the sensors downward in increments of $100 \mu \mathrm{m}$ for a total distance of $15 \mathrm{~cm}$, with sensor data stored internally. After a cycle, the sensors moved back to the starting position until a new measuring cycle was initiated by the ROV.

$\mathrm{O}_{2}$-electrodes had a linear response to $\mathrm{O}_{2}$ concentration in seawater and were calibrated in situ using constant readings in the bottom water $\left(\mathrm{O}_{2}\right.$ concentration determined by Winkler titration) and the anoxic parts of the sediment. Pre-calibration was done on board; however, due to temperature and pressure effects on the sensor performance, an in situ calibration was preferred.

$\mathrm{H}_{2} \mathrm{~S}$-electrodes were calibrated in a degassed phosphate buffer in which the $\mathrm{H}_{2} \mathrm{~S}$ concentration was increased stepwise with known aliquots of a $100 \mathrm{mM}$ $\mathrm{Na}_{2} \mathrm{~S}$ solution (Wenzhoefer et al. 2000). The slope of the $\mathrm{pH}$ electrode measurements was determined by immersing the sensors in seawater at in situ bottom water temperature and subsequently changing the $\mathrm{pH}$ by adding small amounts of $\mathrm{H}_{2} \mathrm{SO}_{4}(10 \% \mathrm{v} / \mathrm{v})$. $\mathrm{pH}$ microelectrode signals were then compared to readings of a commercial pH electrode (Radiometer) calibrated in NBS buffer. Usually, an off-set was observed in the bottom water, which was corrected with $\mathrm{pH}$ determinations from Niskin bottle samples from $50 \mathrm{~cm}$ above the sediment surface.

Diffusive $\mathrm{O}_{2}$ uptake (DOU) was calculated from $\mathrm{O}_{2}$ microelectrode profiles using Fick's First Law of Diffu-

Table 1. Sampling in sediments. A-E are arbitrary core IDs to show which parameters were measured in identical or separate cores at each distance from the whale fall

\begin{tabular}{|c|c|c|c|c|c|c|}
\hline \multirow{2}{*}{ Parameter } & \multicolumn{5}{|c|}{ Distance from whale (m) } & \multirow{2}{*}{$\begin{array}{c}\text { Core } \\
\text { ID }\end{array}$} \\
\hline & 0 & 0.5 & 1 & 3 & 9 & \\
\hline \multicolumn{7}{|l|}{ In situ } \\
\hline Oxygen concentration $^{a}$ & $\mathrm{x}$ & & & $\mathrm{x}$ & $\mathrm{x}$ & \\
\hline $\mathrm{pH}^{\mathrm{a}}$ & $\mathrm{x}$ & & & $\mathrm{x}$ & $\mathrm{x}$ & \\
\hline Sulfide concentration ${ }^{a}$ & $\mathrm{x}$ & & & $\mathrm{x}$ & $\mathrm{x}$ & \\
\hline Oxygen consumption ${ }^{\mathrm{b}}$ & $\mathrm{x}$ & & & & $\mathrm{x}$ & \\
\hline \multicolumn{7}{|l|}{ Ex situ } \\
\hline Sulfate reduction $^{\mathrm{c}}$ & $\mathrm{x}$ & $\mathrm{x}$ & $\mathrm{x}$ & $\mathrm{x}$ & $\mathrm{x}$ & $\mathrm{A}, \mathrm{B}$ \\
\hline Sulfate concentration $^{\mathrm{c}}$ & $\mathrm{x}$ & $\mathrm{x}$ & $\mathrm{x}$ & $\mathrm{x}$ & $\mathrm{x}$ & A \\
\hline Sulfide concentration ${ }^{\mathrm{d}}$ & $\mathrm{x}$ & & $\mathrm{x}$ & & & $\mathrm{C}$ \\
\hline Total organic carbon ${ }^{\mathrm{e}}$ & $\mathrm{x}$ & $x$ & $\mathrm{x}$ & $\mathrm{x}$ & $\mathrm{x}$ & $\mathrm{D}$ \\
\hline Total inorganic carbon ${ }^{\mathrm{e}}$ & $\mathrm{x}$ & $\mathrm{x}$ & $\mathrm{x}$ & $\mathrm{x}$ & $\mathrm{x}$ & $\mathrm{D}$ \\
\hline Total nitrogen & $\mathrm{x}$ & $\mathrm{x}$ & $\mathrm{x}$ & $\mathrm{x}$ & $\mathrm{x}$ & $\mathrm{D}$ \\
\hline Total sulfure & $\mathrm{x}$ & $\mathrm{x}$ & $\mathrm{x}$ & $\mathrm{x}$ & $\mathrm{x}$ & $\mathrm{D}$ \\
\hline Porosity & $\mathrm{x}$ & $\mathrm{x}$ & $\mathrm{x}$ & $\mathrm{x}$ & $\mathrm{x}$ & $\mathrm{D}$ \\
\hline Bacterial cell numbers ${ }^{\mathrm{e}}$ & $\mathrm{x}$ & $\mathrm{x}$ & $\mathrm{x}$ & $\mathrm{x}$ & $\mathrm{x}$ & $\mathrm{D}$ \\
\hline \multicolumn{7}{|l|}{ In vitro } \\
\hline Methanogenesis ${ }^{\mathrm{f}}$ & $\mathrm{x}$ & & $\mathrm{x}$ & $\mathrm{x}$ & & $\mathrm{E}$ \\
\hline Enrichment experiment ${ }^{g}$ & $\mathrm{x}$ & & $\mathrm{x}$ & $\mathrm{x}$ & & $\mathrm{E}$ \\
\hline \multicolumn{7}{|c|}{$\begin{array}{l}\text { a Microprofiler, } 100 \mu \mathrm{m} \text { sampling interval; }{ }^{\text {b }} \text { Benthic cham- } \\
\text { ber; }{ }^{\mathrm{c}-\mathrm{g}} \text { Push core: }{ }^{\mathrm{c}} 1 \mathrm{~cm} \text { interval }{ }^{\mathrm{d}} 1 \text { to } 3 \mathrm{~cm} \text { intervals; }{ }^{\mathrm{e}} 1 \mathrm{~cm} \\
\text { intervals for } 0-5 \mathrm{~cm} \text { depth, and } 2 \mathrm{~cm} \text { interval at }>5 \mathrm{~cm} \text {; } \\
\mathrm{f}_{5} \mathrm{~cm} \text { interval; }{ }^{\mathrm{g}} \text { range } 0-10 \text { or } 0-15 \mathrm{~cm}\end{array}$} \\
\hline
\end{tabular}



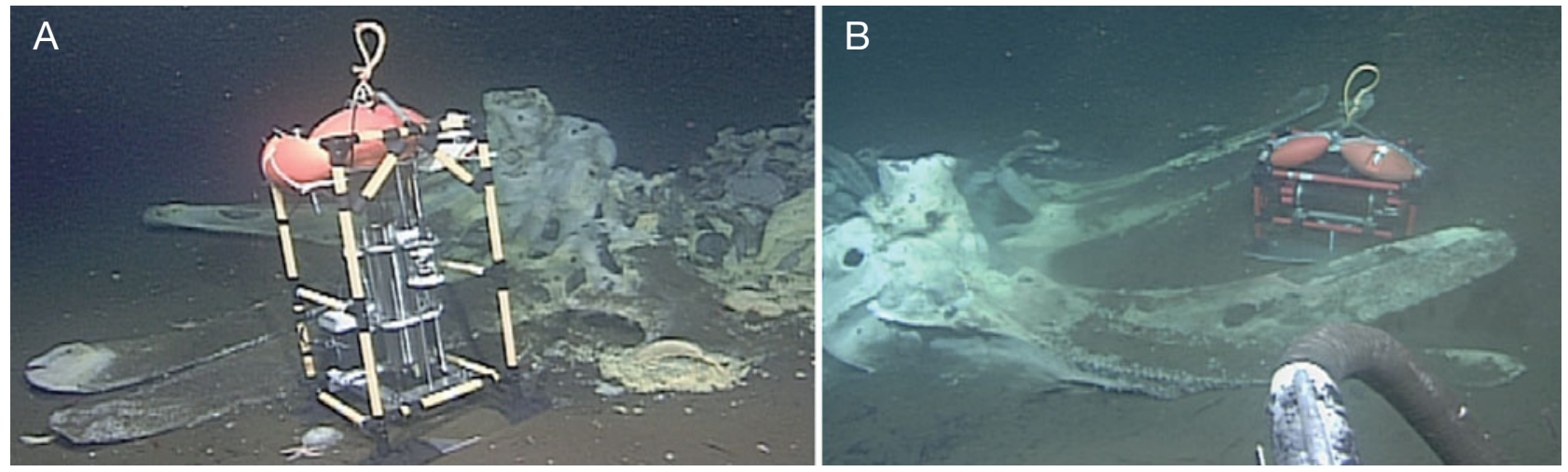

Fig. 2. (A) Microprofiler and (B) benthic chamber at position $0 \mathrm{~m}$ during in situ measurements at the whale-fall head

sion, $\mathrm{DOU}=\mathrm{D}_{0}(\mathrm{dC} / \mathrm{dZ})$, where $\mathrm{D}_{0}$ is the molecular diffusion coefficient of $\mathrm{O}_{2}$ at in situ temperature, salinity and hydrostatic pressure, and $\mathrm{C}$ is $\mathrm{O}_{2}$ concentration at depth $\mathrm{Z}$ within the diffusive boundary layer (Jørgensen \& Revsbech 1985, Rasmussen \& Jørgensen 1992).

Benthic chamber. In 2005, a small frame equipped with a central, stirred cylindrical chamber (internal diameter $=19 \mathrm{~cm}$ ) was deployed at 0 and $9 \mathrm{~m}$ from the whale fall to measure total in situ benthic $\mathrm{O}_{2}$ consumption (Fig. 1B, Table 1). At $0 \mathrm{~m}$, the chamber was placed between the mandibles within an area of black sediment (Fig. 2B). It was not possible to place the chamber on microbial mat due to presence of bones. After the chamber was deployed by the ROV, water height above the sediment inside the chamber was determined from ROV video. The chamber enclosed an area of ca. $285 \mathrm{~cm}^{2}$ together with $\sim 10 \mathrm{~cm}$ of overlying bottom water. Change in $\mathrm{O}_{2}$ concentration over time in the enclosed water volume was continuously monitored by 2 Clark-type mini-electrodes in the chamber lid (incubation times: $1 \mathrm{~h} 15 \mathrm{~min}$ at $0 \mathrm{~m}$ between mandibles, $8 \mathrm{~h}$ $30 \mathrm{~min}$ at $0 \mathrm{~m}$ in black patch, and $3 \mathrm{~h} 00 \mathrm{~min}$ at $9 \mathrm{~m}$ ). The sensors had a reinforced outer casing but had the same measuring characteristics as outlined above for the microprofiler (Glud et al. 2000). The sensors were calibrated against bottom water samples and a zero reading recorded on board at in situ temperature. Total oxygen uptake (TOU) was calculated from the initial linear decrease in $\mathrm{O}_{2}$ concentration versus time in the enclosed water volume.

\section{Sediment samples ex situ}

Collection. Sediment samples were collected near the whale fall with plastic push cores (internal diameter $=7 \mathrm{~cm}$, length $=20 \mathrm{~cm}$ ) operated by the manipulator of the ROV. In 2004, cores were collected at random locations at distances of 0,1 and $3 \mathrm{~m}$ from the whale skeleton (Fig. 1B). In 2005, additional coring was performed at random locations at 0.5 and $9 \mathrm{~m}$ from the whale skeleton. At each distance, 5 parallel push cores were taken from an area of $\sim 25 \times 25 \mathrm{~cm}$ and subsampled on shipboard at $4^{\circ} \mathrm{C}$. An overview of the subsequent push core subsampling is given in Table 1. EX situ refers to undisturbed sediment samples that were taken immediately after push-core recovery, whereas in vitro refers to samples manipulated in the laboratory and studied under defined conditions.

Sulfate reduction (SR) rates. Two push cores (A and $B$, Table 1) taken at each distance from the whale fall were subsampled with 2 to 4 smaller subcores (internal diameter $=2.6 \mathrm{~cm}$, length $=20 \mathrm{~cm}$ ). Subcores were sealed with rubber stoppers with $\sim 5 \mathrm{~cm}$ seawater headspace and transported at $4^{\circ} \mathrm{C}$ to the isotope laboratory (MPI for Marine Microbiology, Bremen, Germany), where they were further processed immediately after arrival ( 7 to $11 \mathrm{~d}$ after sampling). Carrier-free ${ }^{35} \mathrm{SO}_{4}{ }^{2-}$ (dissolved in water, injection volume $=6 \mu \mathrm{l}$, activity $=135 \mathrm{kBq}$, specific activity $=37 \mathrm{TBq}^{\mathrm{mmol}}{ }^{-1}$ ) was injected into 2 to 4 replicate subcores at $1 \mathrm{~cm}$ intervals according to the whole core injection method of Jørgensen (1978). Push cores were incubated in the dark at in situ temperature $\left(4^{\circ} \mathrm{C}\right)$ for $24(2004)$ or $18 \mathrm{~h}$ (2005). After incubation, sediment subcores were sectioned into $1 \mathrm{~cm}$ intervals and transferred into $50 \mathrm{ml}$ plastic centrifuge vials filled with $20 \mathrm{ml}$ zinc acetate $(20 \% \mathrm{w} / \mathrm{w})$. Control subcores were first fixed before addition of tracer. SR rates were determined using the cold chromium distillation method according to Kallmeyer et al. (2004).

Sulfate concentration. At each distance from the whale fall, 1 subcore was taken to determine sulfate concentrations from push cores (A, Table 1) that had been subsampled for SR rates. Subcores were sliced into $1 \mathrm{~cm}$ depth intervals, transferred into $50 \mathrm{ml}$ plastic centrifuge vials filled with $20 \mathrm{ml}$ zinc acetate $(20 \%$ $\mathrm{w} / \mathrm{w})$ and then shaken thoroughly. In the laboratory, samples were centrifuged at $2200 \times g$ for $10 \mathrm{~min}$ and 
pore water sulfate concentrations measured in the supernatant using non-suppressed ion chromatography. The instrument was equipped with a Waters 510 HPLC pump, WISP 712 autosampler (100 $\mu$ l injection volume), IC-Pak anion exchange column $(50 \times 4.6 \mathrm{~mm})$ and a 430 conductivity detector. The eluent was $1 \mathrm{mmol}$ $\mathrm{l}^{-1}$ isophthalic acid with $10 \%$ methanol, adjusted to $\mathrm{pH}$ 4.5. The flow was set to $1.0 \mathrm{ml} \mathrm{min}^{-1}$.

Sulfide concentration. One sediment push core $(C$, Table 1) was taken at each of the 0 and $1 \mathrm{~m}$ distances, placed in an anoxic glove bag and sliced in 1 to $3 \mathrm{~cm}$ depth intervals. Sediment from each interval was transferred into $50 \mathrm{ml}$ syringes, with internal tip ends fitted with $10 \mu \mathrm{m}$ Nytex screening. Polycarbonate $0.2 \mu \mathrm{m}$ filters were fitted onto the syringes and gradual and modest pressure applied to syringe pistons using a press to extract pore water. The first milliliter of filtered pore water obtained from each sample was discarded and the second was transferred into a scintillation vial containing $0.5 \mathrm{ml}$ of $0.05 \mathrm{M}$ zinc acetate. In the laboratory, all samples were analyzed for dissolved sulfide using the colorimetric method of Cline (1969). This method helps determine the concentration of all species of dissolved sulfide $\left(\mathrm{H}_{2} \mathrm{~S}, \mathrm{HS}^{-}, \mathrm{S}^{2-}\right)$.

Carbon-nitrogen-sulfur (CNS), total organic carbon (TOC) and total inorganic carbon (TIC). From one push core (D, Table 1) taken at each distance, $\sim 1.5 \mathrm{~cm}^{3}$ sediment was taken at 1 (between 0 and $5 \mathrm{~cm}$ ) and $2 \mathrm{~cm}$ (below $5 \mathrm{~cm}$ ) depth intervals with cut-off syringes, transferred to $2 \mathrm{ml}$ plastic vials and frozen at $-25^{\circ} \mathrm{C}$. Prior to elemental analysis, samples were freeze-dried and homogenized. Total CNS concentrations were determined by combustion/gas chromatography (Carlo Erba NA-1500 CNS analyzer) with a precision of $\pm 0.6 \%$ for $C, \pm 0.7 \%$ for $N$, and $\pm 0.6 \%$ for $S$. TIC was measured on a CM $5012 \mathrm{CO}_{2}$ Coulometer (UIC) after acidification with $\mathrm{H}_{3} \mathrm{PO}_{4}$. Precision for TIC was $\pm 0.4 \%$. TOC was calculated as the difference between total carbon and TIC.

Bacterial abundance. From one push core (D, Table 1) taken at each distance, a $1 \mathrm{~cm}^{3}$ sediment was taken at $1(0$ to $5 \mathrm{~cm}$ ) and $2 \mathrm{~cm}$ (below $5 \mathrm{~cm}$ ) depth intervals with cut-off syringes immediately after recovery and transferred into vials filled with $9 \mathrm{~cm}^{-3}$ formaldehyde ( $2 \%$ in seawater, $0.22 \mu \mathrm{m}$ filtered) and stored at $4{ }^{\circ} \mathrm{C}$. Total bacterial cell numbers were enumerated using acridine orange direct counts (AODC) according to Meyer-Reil (1983) as modified by Boetius \& Lochte (1996). Grid numbers counted by AODC varied between 10 and 30 with an average of 50 cells per grid.

Methane concentration. From one push core ( $D$, Table 1), taken at each distance, $2 \mathrm{~cm}^{3}$ of sediment was taken at $1(0$ to $5 \mathrm{~cm}$ ) and $2 \mathrm{~cm}$ (below $5 \mathrm{~cm}$ ) depth increments with cut-off syringes and transferred into $10 \mathrm{ml}$ glass vials filled with $5 \mathrm{ml} \mathrm{NaOH}(2.5 \% \mathrm{w} / \mathrm{w})$ to stop microbial activity. Vials were closed quickly with butyl rubber stoppers, sealed with aluminum crimps and shaken thoroughly to equilibrate pore water methane into the headspace. In the laboratory, methane concentrations were determined by injection of $200 \mu l$ headspace into a gas chromatograph (5890A, Hewlett Packard) equipped with a packed stainless steel Porapak-Q column $(1.83 \mathrm{~m} \times 0.32 \mathrm{~cm}, 80 / 100$ mesh, Agilent Technologies) and a flame ionization detector. Carrier gas was helium at a flow rate of $30 \mathrm{ml}$ $\mathrm{min}^{-1}$. Column temperature was set to $40^{\circ} \mathrm{C}$.

Dry weight, density and porosity. From one push core (D, Table 1) taken at each distance, 5 to $10 \mathrm{~cm}^{3}$ sediment was taken at $1 \mathrm{~cm}(0$ to $5 \mathrm{~cm}$ ) and $2 \mathrm{~cm}$ (below $5 \mathrm{~cm}$ ) depth increments, transferred into pre-weighed $15 \mathrm{ml}$ plastic centrifuge vials with a volume scale bar, closed with a plastic screw cap and stored at $4^{\circ} \mathrm{C}$. In the laboratory, vials were centrifuged at $2200 \times g$ for $10 \mathrm{~min}$, weighed, filled with water to a defined volume, weighed again, dried and weighed a third time. Density was calculated by dividing sediment wet weight by sediment volume (sediment volume with added water minus volume of added water). Porosity was calculated by dividing pore water volume by sediment volume. Density and porosity data were used for calculations of SR and in vitro turnover rates.

\section{Sediments samples in vitro}

Methanogenesis (MG) rates. Potential MG was measured in vitro without addition of methanogenic substrates as described in Krüger et al. (2001). Sediment samples were taken with a push core (E, Table 1$)$ at 0 , 1 and $3 \mathrm{~m}$ from the whale fall. Cores were sliced at 5 $\mathrm{cm}$ intervals. Sediment was transferred into glass bottles, sealed headspace-free with rubber stoppers and stored anoxically at $4^{\circ} \mathrm{C}$ in the dark until further processing. In the laboratory, subsamples of 0 to 5 and 5 to $10 \mathrm{~cm}$ depth intervals were mixed with artificial seawater medium with and without $28 \mathrm{mM}$ sulfate (Widdel \& Bak 1992) to obtain homogenous slurries; $3 \mathrm{ml}$ of anoxic sediment slurries were then transferred into sterile glass tubes. An additional $9 \mathrm{ml}$ of artificial sulfate-rich $(28 \mathrm{mM})$ and sulfate-free seawater medium, respectively, were added and tubes were sealed with butyl stoppers. The headspace consisted of a $\mathrm{N}_{2} / \mathrm{CO}_{2}$ mixture (90:10). All incubations were done in triplicate at $4^{\circ} \mathrm{C}$. Headspace samples $(0.1 \mathrm{ml})$ were taken with pressure-lock syringes twice per day after shaking of the tubes by hand, and analyzed for methane using a GC 14B gas chromatograph (Shimadzu) equipped with a Supel-Q Plot column (30 m ×0.53 mm; Supelco) and a flame ionization detector (Nauhaus et al. 2002). Sediment dry mass was determined after drying at $80^{\circ} \mathrm{C}$ for 
2 d. Rates were calculated per volume undiluted sediment from the known sediment volume/dry weight ratio (see 'Dry weight, density and porosity').

Sediment enrichment experiment. This experiment was designed to investigate the change in microbial activity (methane and sulfide production) in sediments collected from around the whale fall $(0,1$ and $3 \mathrm{~m}$ ) after addition of new whale biomass. For biomass addition, we used flesh and oil from a common porpoise provided by the Forschungs- und Technologiezentrum Westkueste, Buesum, Germany. Whale biomass was frozen before use. The experiment was conducted under an $\mathrm{N}_{2} / \mathrm{CO}_{2}$ atmosphere (90:10) to ensure anoxic conditions. Homogenous sediment slurries (on average $0.12 \mathrm{~g}$ dry weight per $\mathrm{ml}$ ) were prepared with sulfate-rich (28 $\mathrm{mM})$ artificial seawater medium (Widdel \& Bak 1992) from depth sections 0 to $10 \mathrm{~cm}(0 \mathrm{~m})$ and 0 to $15 \mathrm{~cm}(1$ and $3 \mathrm{~m})$ of push cores (E, Table 1). From the slurries, $150 \mathrm{ml}$ were transferred into glass crimp vials $(243 \mathrm{ml})$ and $16 \mathrm{~g}$ thawed whale flesh plus $4 \mathrm{~g}$ thawed whale oil were added. In total, this accounted for an addition of $\sim 14 \mathrm{~g}$ total organic carbon (TOC flesh: $716 \pm 20 \mu \mathrm{gg}^{-1}, \mathrm{n}=19$; TOC oil: $730 \pm 43 \mu \mathrm{g} \mathrm{mg}{ }^{-1}, \mathrm{n}=18$; raw data not shown) and corresponded to an increase in organic carbon in the slurries of $\sim 4$ - to 16 -fold, depending on the initial TOC content of the sediment (5 to $20 \%$ of dry weight, see 'Results'); 3 replicates and 1 control (sediment slurry without whale biomass addition) were prepared for each distance, as well as 3 additional controls without sediment containing only $150 \mathrm{ml}$ artificial seawater medium plus whale flesh and oil. Vials were closed with rubber stoppers and aluminum crimps and stored in the dark at $4^{\circ} \mathrm{C}$. The increase in sulfide concentration (in the supernatant) and methane (in the headspace) was first monitored every other day and on a weekly basis after $50 \mathrm{~d}$. Sulfide in the supernatant was determined colorimetrically using the formation of colloidal copper sulfide (Cord-Ruwisch 1985). Methane was determined in the headspace using a gas chromatograph (5890A, Hewlett Packard) equipped with a packed stainless steel Porapak-Q column $(1.83 \mathrm{~m} \times 0.32 \mathrm{~cm}, 80 / 100$ mesh, Agilent Technologies) and a flame ionization detector. Carrier gas was helium at a flow rate of $30 \mathrm{~cm}^{3} \mathrm{~min}^{-1}$. Column temperature was $40^{\circ} \mathrm{C}$. At the beginning and after $33 \mathrm{~d}$, sediments were subsampled and analyzed for bacterial abundance as described above. When sulfide concentrations exceeded $20 \mathrm{mM}$ in the sediments with whale biomass (after 25 and $33 \mathrm{~d}$ ), $50 \mathrm{ml}$ of the supernatant was replaced by fresh artificial seawater medium. During medium exchange, bottles were opened, i.e. the headspace was exchanged as well. To ensure a complete removal of the headspace, vials were additionally purged with nitrogen for $1 \mathrm{~min}$.

\section{Bone investigations in vitro}

Sample preparation. In 2004, one large vertebra (central disk diameter $=\sim 23 \mathrm{~cm}$ ) was collected by ROV and sealed in a plastic box. On shipboard, the vertebra was sagittally sectioned at $4^{\circ} \mathrm{C}$. Small $(\sim 1 \times 1 \times 1$ or $2 \mathrm{~cm}$ ) bone subsamples were removed with a sterilized cutter at 3 depths ( 0 to 1,1 to 3 and 3 to $5 \mathrm{~cm}$ ) from the bone surface. Additionally, large bone pieces were cut out $\sim 5 \mathrm{~cm}$ deep into the bone. Bone samples were transferred to glass bottles filled with sterile filtered anoxic artificial seawater, closed without headspace and stored for $2 \mathrm{wk}$ at $4{ }^{\circ} \mathrm{C}$ until further processing.

Sulfate reduction (SR) rates in bones. Pre-weighed pieces $(0.5$ to $1.6 \mathrm{~g}$ ) of the whale vertebra (3 to 4 replicates per stratum) were incubated separately in $10 \mathrm{ml}$ glass vials filled with anoxic artificial seawater medium (sulfate concentration 28 mM; Widdel \& Bak 1992) and carrier-free ${ }^{35} \mathrm{SO}_{4}{ }^{2-}$ (dissolved in water, activity = $87 \mathrm{kBq}$, specific activity $=37 \mathrm{TBq} \mathrm{mmol}^{-1}$ ). Controls containing only seawater medium (no bones) were incubated in parallel. Incubation was at $4^{\circ} \mathrm{C}$ in the dark for $17 \mathrm{~d}$. After incubation, samples were treated as mentioned above (see 'Sulfate reduction (SR) rates').

Visualization of sulfide emissions from bones. Large pieces of the vertebra were incubated with ${ }^{35} \mathrm{~S}$-sulfate tracer to visualize hot spots of microbial sulfide production in the bone as well as emissions of sulfide from the bone into the water column; 2 replicate $\sim 5 \mathrm{~cm}$ long bone pieces (cut from bone-water interface towards inner bone center) were attached to silver foil (see Fig. 8) and incubated with ${ }^{35} \mathrm{SO}_{4}{ }^{2-}$ (dissolved in water, activity $=870 \mathrm{kBq}$, specific activity $=37 \mathrm{TBq} \mathrm{mmol}^{-1}$ ) for $49 \mathrm{~d}$ in $40 \mathrm{ml}$ glass vials with anoxic artificial seawater medium (sulfate concentration $28 \mathrm{mM}$; Widdel \& Bak 1992) at $4^{\circ} \mathrm{C}$ in the dark. One additional piece of silver foil was incubated without bone as a control. During incubation, a portion of the ${ }^{35} \mathrm{~S}$-sulfide produced from ${ }^{35} \mathrm{~S}$-sulfate reacted with the silver foil with ${ }^{35} \mathrm{~S}$-sulfur binding as $\mathrm{Ag}_{2} \mathrm{~S}$. After incubation, silver foils were removed from bones and the 2-dimensional distribution of ${ }^{35} \mathrm{~S}$-activity on the foils was measured by scanning with a high-resolution 2D $\mu$-IMAGER (Biospace Mésures) (Lanièce et al. 1998) with a resolution of $15 \mu \mathrm{m}$.

\section{RESULTS}

\section{Visual estimation of high-sulfide areas}

Bone area with bacterial mats. Bone coverage by bacterial mats was estimated from 37 and 43 bones photographed in 2004 and 2005, respectively (Table 2). The lower number of bones observed in 2004 is 
Table 2. Visible bone plan area covered by bacterial mat on the Santa Cruz whale skeleton in 2004 and 2005. Bacterial mats (yellow/white) were distinguished visually from brown-grayish bones in digital color pictures. $\mathrm{N}=$ number of bones analyzed. Kruskal-Wallis tested for significant differences in cover between years. ${ }^{*} \mathrm{p}<0.05 ;{ }^{* *} \mathrm{p}<0.01$

\begin{tabular}{|c|c|c|c|c|c|c|}
\hline \multirow[b]{2}{*}{ Bone class } & \multirow[b]{2}{*}{$\mathrm{N}$} & \multirow{2}{*}{$\begin{array}{l}2004 \\
\text { Cover }(\%)\end{array}$} & \multirow[b]{2}{*}{ SE $(\%)$} & \multirow[b]{2}{*}{$\mathrm{N}$} & \multirow{2}{*}{$\begin{array}{r}2005 \\
\text { Cover }(\%)\end{array}$} & \multirow[b]{2}{*}{ SE $(\%)$} \\
\hline & & & & & & \\
\hline Skull & 1 & 97 & - & 1 & 94 & - \\
\hline Mandibles/maxillae & 4 & 61 & 10 & 4 & 45 & 15 \\
\hline Scapula & 2 & 44 & 16 & 2 & 60 & 19 \\
\hline Rib & 12 & 78 & 6 & 14 & 76 & 8 \\
\hline Vertebrae & 18 & $82^{* *}$ & 4 & 22 & $51^{* *}$ & 6 \\
\hline Thorax & 8 & $94^{* *}$ & 3 & 11 & $58^{* *}$ & 11 \\
\hline Lumbar & 5 & 77 & 8 & 6 & 55 & 9 \\
\hline Caudal & 5 & $67^{*}$ & 9 & 5 & $32^{*}$ & 5 \\
\hline
\end{tabular}

partly due to a greater extent of bacterial mats, which often prevented delineation of bones. Percent bacterial mat cover was generally lower in 2005 than in 2004 (Table 2). Skull bones and ribs had high and relatively stable coverage of bacterial mats (>95 and $75 \%$, respectively) in both years. These bones were positioned further above the seafloor, which made them very visible in all images and limited the accumulation of sediments resuspended by the ROV during previous sampling in 2002 and 2004, as observed on flatter bones near the seafloor (e.g. jaws and scapulae). There was a significant difference in bacterial mat coverage on the vertebrae between years, with thoracic and caudal vertebrae sustaining a $~ 30 \%$ decrease in mat coverage from 2004 to 2005 (Table 2). Pooling of all vertebrae also yielded a significant $31 \%$ decrease in mat coverage from 2004 to 2005 (Kruskal-Wallis test, $\mathrm{p}=0.001$ ).

Sediment area with bacterial mats and black patches. The total seafloor area within $0.5 \mathrm{~m}$ of the whale skeleton was 17.7 to $18.1 \mathrm{~m}^{2}$ with $48 \%$ in the head region, $38 \%$ in the thoracic region and $14 \%$ in the lumbar region (Table 3). Generally, bacterial mats occupied slightly more sediment area (13 and 12\% in 2004 and 2005, respectively) around the whale fall than the black patches without bacterial mats $(10$ and $5 \%$, respectively) (Table 3). Both habitat types were concentrated in the skull and thoracic regions of the skeleton. Around the entire whale fall, bacterial mat coverage on sediments was relatively stable, decreasing slightly by $7 \%$ between 2004 and 2005. A decrease in mat coverage in the skull and lumbar regions was offset by the large increase in coverage in the thoracic region. The area of black sediment patches around the entire skeleton decreased by more than $50 \%$ between 2004 and 2005. The combined area of bacterial mat and black sediments declined by $23 \%$ between 2004 and 2005, suggesting a decline in availability of sulfide-rich sedimentary habitats around the whale fall over this period.

\section{Sediment investigations in situ}

Oxygen microprofiles. Bottom-water oxygen concentration was $\sim 260 \mu \mathrm{M}$, corresponding to $79 \%$ saturation. Within the seafloor, oxygen decreased rapidly within the upper $5 \mathrm{~mm}$ of sediment (Fig. 3). At 3 and $9 \mathrm{~m}$ from the whale fall, oxygen concentrations decreased to zero within the first 3 to $4 \mathrm{~mm}$ of the sediment, while oxygen was completely consumed within the top millimeter at $0 \mathrm{~m}$ in black sediment.

Oxygen consumption rates. TOU determined in the benthic chamber was slightly higher (1.5 times) than DOU determined from oxygen profiles (Table 4), which might be due to faunally mediated oxygen consumption (e.g. bioirrigation and macrofaunal respiration). Generally, TOU and DOU were higher closer to the whale fall (33 to 36 and $24 \mathrm{mmol} \mathrm{m}^{-2} \mathrm{~d}^{-1}$, respectively), but the decrease in consumption with distance from the whale fall was less than $40 \%$.

Sulfide microprofiles. No free sulfide was detected down to the maximum depths to which microsensors penetrated, i.e. $40 \mathrm{~mm}$ depth at $9 \mathrm{~m}, 30 \mathrm{~mm}$ at $3 \mathrm{~m}$ and

Table 3. Estimated surface area $\left(\mathrm{m}^{2}\right)$ of total sediment, bacterial mats and black sediments within $0.5 \mathrm{~m}$ of the whale skeleton in 2004 and 2005. Total sediment area includes bacterial mats, black sediments and other (non-reduced) sediments. Bacterial mats (yellow/white) and black sediments were distinguished visually from brownish-green, non-reduced sediments in digital color pictures. Error is the percentage difference in total sediment area between 2004 and 2005

\begin{tabular}{|c|c|c|c|c|c|c|c|c|c|c|c|}
\hline \multirow{4}{*}{$\frac{\text { Carcass region }}{\text { Head }}$} & \multicolumn{3}{|c|}{ Total sediment } & \multicolumn{4}{|c|}{$\longrightarrow$ Bacterial mat -} & \multicolumn{4}{|c|}{$\longrightarrow$ Black sediment } \\
\hline & \multirow{3}{*}{$\begin{array}{c}2004 \\
\text { Area }\left(\mathrm{m}^{2}\right) \\
8.7\end{array}$} & \multirow{3}{*}{$\begin{array}{c}2005 \\
\text { Area }\left(\mathrm{m}^{2}\right) \\
8.7\end{array}$} & \multirow{3}{*}{$\begin{array}{c}\begin{array}{c}\text { Error } \\
(\%)\end{array} \\
<1\end{array}$} & \multirow{2}{*}{\multicolumn{4}{|c|}{$\begin{array}{cc}2004- & 2005- \\
\text { Area }\left(\mathrm{m}^{2}\right) \text { Cover }(\%) & \text { Area }\left(\mathrm{m}^{2}\right) \text { Cover }(\%)\end{array}$}} & \multirow{2}{*}{\multicolumn{2}{|c|}{ 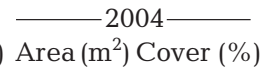 }} & \multirow{2}{*}{\multicolumn{2}{|c|}{$\begin{array}{c}2005- \\
\text { Area }\left(\mathrm{m}^{2}\right) \text { Cover }(\%)\end{array}$}} \\
\hline & & & & & & & & & & & \\
\hline & & & & 0.95 & 11 & 0.35 & 4 & 0.62 & 7 & 0.32 & 4 \\
\hline Thorax & 6.5 & 7 & 8 & 1.0 & 16 & 1.6 & 23 & 0.98 & 15 & 0.35 & 5 \\
\hline Lumbar & 2.6 & 2.4 & 9 & 0.36 & 14 & 0.25 & 11 & 0.13 & 5 & 0.24 & 10 \\
\hline Whole carcass & 17.7 & 18.1 & 2 & 2.3 & 13 & 2.2 & 12 & 1.7 & 10 & 0.91 & 5 \\
\hline
\end{tabular}


$0 \mathrm{~m}$ distance

Oxygen $(\mu \mathrm{M})$
$3 \mathrm{~m}$ distance

Oxygen $(\mu \mathrm{M})$

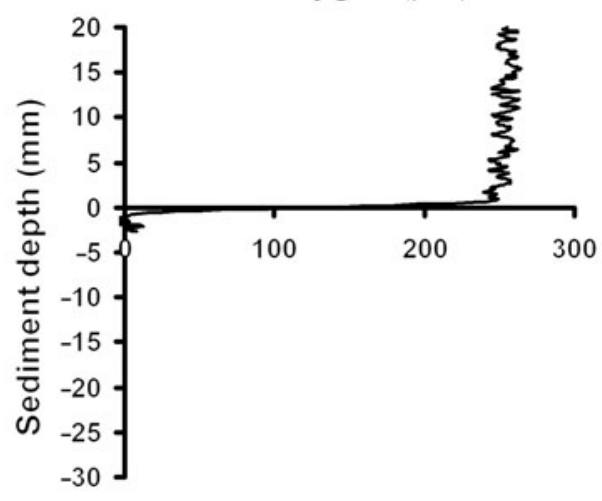

$\mathrm{pH}$

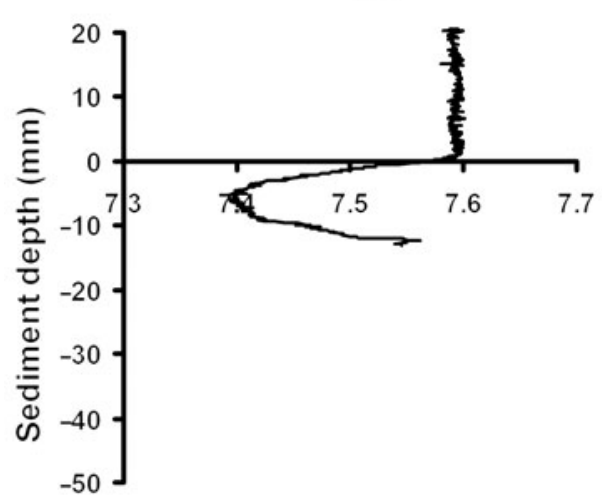

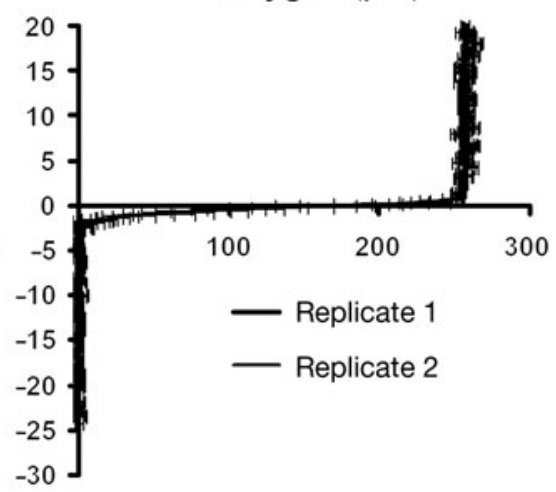

$\mathrm{pH}$
$9 \mathrm{~m}$ distance

Oxygen $(\mu \mathrm{M})$

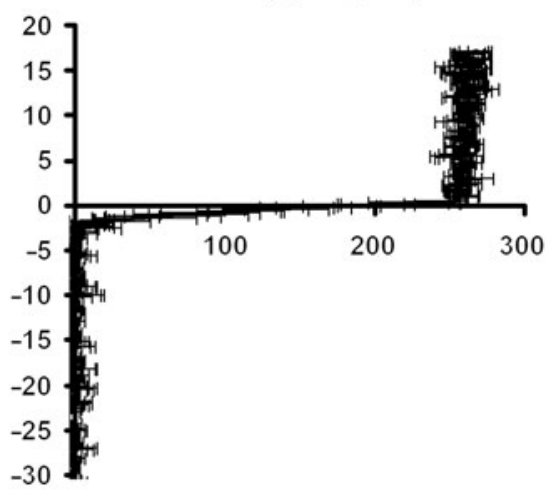

$\mathrm{pH}$

Fig. 3. In situ sediment microprofiles of oxygen and $\mathrm{pH}$ measured at distances of 0,3 and $9 \mathrm{~m}$ from the whale fall. The $0 \mathrm{~m}$ profile was measured in a black sediment patch. Oxygen at 3 and $9 \mathrm{~m}$ was measured in triplicate (SD are given)

$20 \mathrm{~mm}$ at $0 \mathrm{~m}$ (black sediment patch) from the whale fall. Since calibrations of sulfide electrodes before and after deployment were successful, sensor malfunction can be excluded.

pH microprofiles. In situ pH of $\sim 7.6$ in the bottom water decreased with depth into the sediment at all distances from the whale fall, reaching a minimum of

Table 4. Areal rates $\left(\mathrm{mmol} \mathrm{m} \mathrm{m}^{-2} \mathrm{~d}^{-1}\right)$ of oxygen consumption in situ, sulfate reduction ex situ $(0-10 \mathrm{~cm})$ and methane production in vitro $(0-10 \mathrm{~cm})$ in the presence of sulfate in sediments around the whale fall. Means \pm SD (n) are given. Please notice that in situ/ex situ data should not be directly compared with potential rates determined in vitro. DOU: Diffusive oxygen uptake; TOU: Total oxygen uptake; nd: not determined

\begin{tabular}{|lcccc|}
\hline $\begin{array}{l}\text { Distance } \\
(\mathrm{m})\end{array}$ & DOU & TOU & $\begin{array}{c}\text { Sulfate } \\
\text { reduction }\end{array}$ & $\begin{array}{c}\text { Methane } \\
\text { production }\end{array}$ \\
\hline 0 & $24.3^{\mathrm{a}}$ & $36.3^{\mathrm{a}}, 32.8^{\mathrm{b}}$ & $307^{\mathrm{c}} \pm 459(4)$ & $79^{\mathrm{c}} \pm 8.0(3)$ \\
0.5 & nd & nd & $707^{\mathrm{a}} \pm 1008(4)$ & nd \\
1 & nd & nd & $0.39 \pm 0.38(3)$ & $1.1 \pm 0.07(3)$ \\
3 & $18.7 \pm 0.62(4)$ & nd & $0.05 \pm 0.08(3)$ & $0.29 \pm 0.03(3)$ \\
9 & $14.8 \pm 0.84(3)$ & 22.3 & $0.18 \pm 0.04(2)$ & nd \\
${ }^{\text {aBlack patch, }}$ b between jaw bones, chacterial mat & \\
\hline
\end{tabular}

7.5 at $15 \mathrm{~mm}(3$ and $9 \mathrm{~m})$ and 7.4 at $5 \mathrm{~mm}(0 \mathrm{~m}$, black sediment) (Fig. 3). This sharp decrease in $\mathrm{pH}$ below the sediment-water interface most likely resulted from aerobic degradation of organic matter and fermentation (Soetaert et al. 2007). The subsequent increase in $\mathrm{pH}$ below the minimum peak, reaching nearly sea-water $\mathrm{pH}$ levels, indicates mineralization reactions of sulfide with $\mathrm{Fe}$ and $\mathrm{Mn}$ (Reimers et al. 1996).

\section{Sediment samples ex situ}

Sediment core description. Sediment cores taken in 2004 and 2005 at different distances from the whale fall for ex situ and in vitro investigations revealed distinct differences in color, biota and other visible parameters. At 3 and $9 \mathrm{~m}$, cores were olive green throughout (i.e. $\sim 15 \mathrm{~cm}$ depth). Many of these cores contained signs of bioturbation activity (e.g. burrows). At $1 \mathrm{~m}$, cores were olive 
green in the top $7 \mathrm{~cm}$ and below $13 \mathrm{~cm}$; in between, sediment was dark grey. Many cores had mud tubes formed by the ampharetid polychaete Glyphanostomum sp. nov. protruding from the sediment surface. At $0.5 \mathrm{~m}$ distance from the whale fall, cored sediments were completely black, smelled of sulfide and contained pieces of whale blubber. Below $10 \mathrm{~cm}$ cores were highly gassy. At $0 \mathrm{~m}$, the sediment surface of cores was covered by a thick yellow mat of filamentous sulfur bacteria (probably Beggiatoa spp.). Beneath the mats, sediments were black to the bottom of the cores and sometimes revealed a pinkish-white smearing of a soft substance along core walls, which could indicate precipitation of calcium palmitate (soap) during biomass decay (Allison 1988). The whole sediment was very oily and foamy with gas bubbles. A strong smell of sulfide and putrifying flesh was present.

Sulfate reduction rates. Vertical profiles of SR were averaged for each distance from the whale fall to show general trends (Fig. 4). Two clusters of SR rates were observed: rates at 1, 3 and 9 m clustered between 0 and $36 \mathrm{nmol} \mathrm{cm}{ }^{-3} \mathrm{~d}^{-1}$, while rates at 0 and $0.5 \mathrm{~m}$ were typically 1 to 3 orders of magnitude higher (reaching $33000 \mathrm{nmol} \mathrm{cm}{ }^{-3} \mathrm{~d}^{-1}$ in single peaks). At $9 \mathrm{~m}$, the profile was relatively uniform with depths to $16 \mathrm{~cm}$. At 1 and $3 \mathrm{~m}$, SR rates peaked at the surface and at depth. At 0 and $0.5 \mathrm{~m}$, rates were relatively high throughout the sediment column with subsurface peaks between 2 and $9 \mathrm{~cm}$. It must be emphasized that for logistical reasons SR cores could not be incubated immediately after retrieval (see 'Materials and methods') and SR rates may have been slightly altered during core storage. It is most likely that SR rates decreased during storage due to a decrease in sulfate concentrations over time, even though a small sulfate pool was provided in the supernatant seawater of the cores. From averaged SR rates in cores, areal rates were calculated, integrated over 0 to $10 \mathrm{~cm}$ depth (Table 4). Areal rates were several orders of magnitudes higher near the whale fall ( 0 and $0.5 \mathrm{~m}, 300$ to $700 \mathrm{mmol} \mathrm{m} \mathrm{m}^{-2}$ ) than at greater distances $\left(1,3\right.$ and $\left.9 \mathrm{~m}, \ll 1 \mathrm{mmol} \mathrm{m}^{-2} \mathrm{~d}^{-1}\right)$. All rates revealed very high SDs, caused by high variability between subcores taken from the ROV push cores, likely due to local heterogeneities in organic matter content.

Sulfate concentration. Pore water sulfate concentrations were in good accordance with observed sulfate turnover. Concentrations changed little from average seawater values $(28 \mathrm{mM})$ over the top 8 to $15 \mathrm{~cm}$ at 3 and $9 \mathrm{~m}$ (Fig. 4). At $1 \mathrm{~m}$, concentrations showed only a slight decrease to $15 \mathrm{~cm}$ sediment depth, falling to values between 20 and $25 \mathrm{mM}$. At 0 and $0.5 \mathrm{~m}$, sulfate concentrations decreased strongly below 7 and $5 \mathrm{~cm}$ depths, respectively, to values between 5 and $10 \mathrm{mM}$.
Sulfide concentration. Sediment pore water sulfide concentrations are available only for the upper $8 \mathrm{~cm}$ of sediment cores taken in 2004 at 0 (below bacterial mat cover) and $1 \mathrm{~m}$ (Fig. 4). Concentrations differed dramatically between distances, with maximum values around $10 \mu \mathrm{M}$ at $1 \mathrm{~m}$ and maximum values of 1000 to $4000 \mu \mathrm{M}$ under the bacterial mat at $0 \mathrm{~m}$. Sulfide profiles at $0 \mathrm{~m}$ revealed maximum concentrations at 5 to $7 \mathrm{~cm}$, which correlated with peaks in SR rates.

Sulfur content. Sulfur content was lowest at $9 \mathrm{~m}$ (around $0.2 \%$ sediment dry weight) and did not change with sediment depth (Fig. 4). Sulfur content gradually increased with proximity to the whale fall reaching a maximum level of $1.4 \%$ at $0 \mathrm{~m}$. The only exception was the $3 \mathrm{~m}$ distance, which revealed higher levels than at $1 \mathrm{~m}$. At $0.5 \mathrm{~m}$, the sulfur profile decreased from surface (1.1 to $1.3 \%$ between 0 and $4 \mathrm{~cm}$ ) to $0.4 \%$ between 6 and $8 \mathrm{~cm}$. Below this depth, the content slightly increased. At $0 \mathrm{~m}$, sulfur content varied substantially over depth but generally remained high.

Nitrogen content. Sediment nitrogen contents revealed a distribution similar to sulfur (Fig. 4). Nitrogen content was generally lowest at $9 \mathrm{~m}$ (around $0.6 \%$ sediment dry weight) and increased to a maximum level of $1.3 \%$ at $0 \mathrm{~m}$. As for sulfur, the $3 \mathrm{~m}$ sample had a higher content than the $1 \mathrm{~m}$ sample. At $0.5 \mathrm{~m}$, the profile dropped from $1.1 \%$ at the surface to $0.3-0.4 \%$ between 6 and $8 \mathrm{~cm}$. Below this depth, values slightly increased. There was a distinct peak $(1.3 \%)$ in nitrogen at 4 to $5 \mathrm{~cm}$ depth at $0 \mathrm{~m}$ distance from the fall.

Total organic carbon content. TOC contents were lowest at 1, 3 and $9 \mathrm{~m}$ (Fig. 4), with values around $5 \%$ sediment dry weight at all sediment depths. At $0.5 \mathrm{~m}$, TOC revealed a trend similar to elemental sulfur and nitrogen: values dropped from a very high level (15\%) at the sediment surface to low levels ( 2 to $3 \%$ ) between 6 and $8 \mathrm{~cm}$, and then increased slightly below $8 \mathrm{~cm}$. At $0 \mathrm{~m}$, TOC was elevated above background levels from the sediment surface to $11 \mathrm{~cm}$ in depth, with peaks (17 and $20 \%$ ) at 1 to 2 and 5 to $6 \mathrm{~cm}$.

Microbial abundance. Microbial cell numbers varied between 1 and $4 \times 10^{9}$ cells $\mathrm{cm}^{-3}$ at 1, 3 and $9 \mathrm{~m}$ (Fig. 4). Values generally decreased from top to bottom $(15 \mathrm{~cm})$ of cores. No values are available for $0.5 \mathrm{~m}$. At $0 \mathrm{~m}$, cell abundance was elevated (maximum of $7 \times 10^{9}$ cells $\mathrm{cm}^{-3}$ ) and the profile roughly followed the shape of the TOC profile suggesting an enrichment of microbial biomass through availability of whale-fall carbon.

Methane concentration. Methane concentrations generally increased exponentially with proximity to the whale fall (Fig. 4). One exception found was at $9 \mathrm{~m}$, where levels were consistently higher than at $3 \mathrm{~m}$. Methane measurements in the sample headspace were at the detection limit $(<5 \mathrm{ppmv})$ at $3 \mathrm{~m}$. The highest methane values were reached at $0 \mathrm{~m}$ with a maximum of 

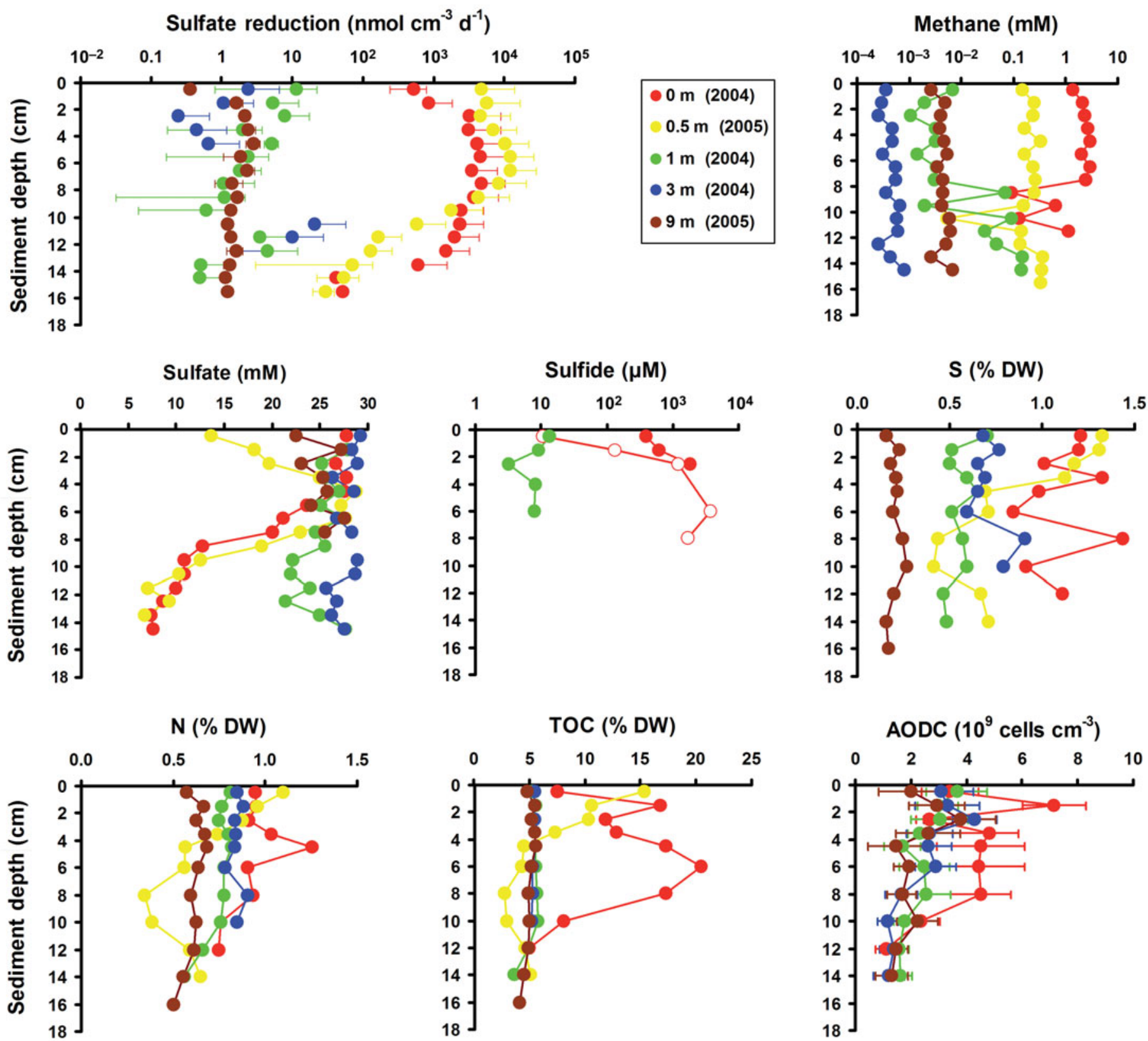

Fig. 4. Ex situ sediment profiles of biogeochemical parameters around the whale fall. Note that x-axes of sulfate reduction (SR) rates as well as methane and sulfide concentrations are on a logarithmic scale. SR rate profiles and acridine orange direct counts (AODC) of microbial cells are averages. Numbers of replicates for SR are given in Table 4. SD attaining zero could not be plotted because of the logarithmic scale. The $0 \mathrm{~m}$ profiles were measured in sediments covered by bacterial mats; replicate measurements for sulfide at $0 \mathrm{~m}$ are shown by filled and open red circles; the $0.5 \mathrm{~m}$ profiles are from black sediment patches. DW: dry weight. TOC: total organic carbon

$2.9 \mathrm{mM}$ at 6 to $7 \mathrm{~cm}$ sediment depth. In cases where methane concentrations reached atmospheric saturation levels ( 1.4 $\mathrm{mM}$ for seawater at $4^{\circ} \mathrm{C}$; Yamamoto et al. 1976), the cores may have lost significant proportions of the dissolved methane during core retrieval and/or decompression from depth. Degassing of methane was obvious from the foamy consistency of sediments from $0 \mathrm{~m}$. Hence, methane concentrations determined ex situ for 0 $\mathrm{m}$ were probably much lower than actual in situ levels.

\section{Sediment samples in vitro}

Methanogenesis rates. Potential microbial MG rates in slurries of sediment from the whale fall area differed by orders of magnitude related to their original proximity to the whale fall (from 1 to $\sim 1000 \mathrm{nmol} \mathrm{cm}^{-3} \mathrm{~d}^{-1}$, Fig. 5). Although $\mathrm{MG}$ rates were either similar or higher in deeper sediments (5 to $10 \mathrm{~cm}$ ) compared to shallow sediments $(0$ to $5 \mathrm{~cm}$ ) at 0 and $3 \mathrm{~m}$, MG rates 

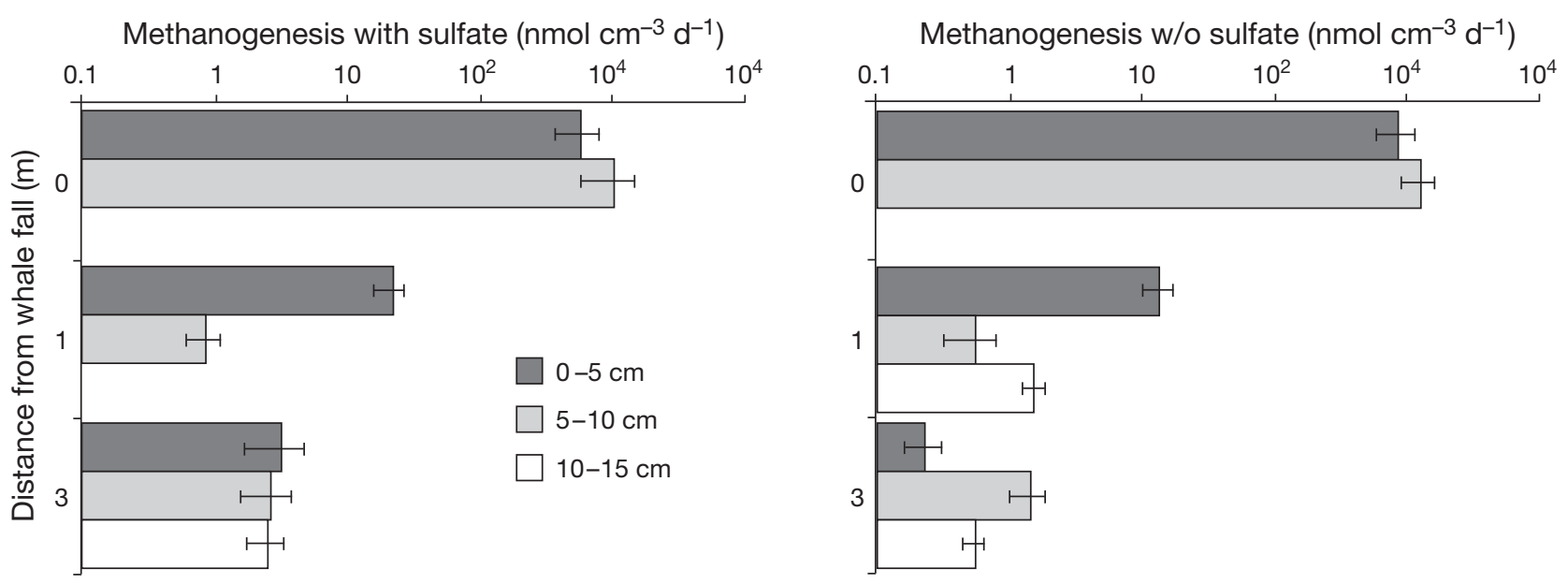

Fig. 5. In vitro methanogenesis (MG) rates (mean $\pm \mathrm{SD}$ ) in sediment slurries from distances of 0,1 and $3 \mathrm{~m}$ from the whale fall as a function of sediment depth $(0-5,5-10$ and $10-15 \mathrm{~cm})$ with (left) or without sulfate (right). At 0 m, no sediment was available from the $10-15 \mathrm{~cm}$ depth stratum. Rates are given for the original, i.e. undiluted, sediment

were higher in shallow sediments $(0$ to $5 \mathrm{~cm})$ at $1 \mathrm{~m}$. This peak was surprising, since the upper $7 \mathrm{~cm}$ of the sediment was olive green, i.e. apparently nonreduced, and bioturbated. Reduced conditions during anoxic incubation may have enabled methanogens to become active and to utilize carbon in this sediment layer. At $0 \mathrm{~m}, \mathrm{MG}$ was 29 and $15 \%$ (0 to 5 and 5 to $10 \mathrm{~cm}$, respectively) higher in slurries without sulfate compared to slurries with sulfate $(28 \mathrm{mM})$. From mean MG rates per $\mathrm{cm}^{3}$ of sediment (with sulfate present) in 0 to 5 and 5 to $10 \mathrm{~cm}$ depth intervals, potential areal rates were calculated, integrated over 0 to $10 \mathrm{~cm}$ sediment depth (Table 4 ). These potential areal rates were relatively low ( $\leq 1 \mathrm{mmol} \mathrm{m}^{-2} \mathrm{~d}^{-1}$ ) at 1 and $3 \mathrm{~m}$, and 2 to 3 orders of magnitude higher in samples from $0 \mathrm{~m}$.

Sediment enrichment experiment. All 3 types of sediment slurries $(0,1$ and $3 \mathrm{~m}$ from the whale fall) revealed strong sulfide production immediately after addition of new whale biomass (Fig. 6). Sediment controls (slurries without added whale biomass) as well as medium controls (whale biomass with only seawater medium) showed no notable increases in sulfide over the course of the experiment. A background level of sulfide was always present, because sulfide was used during medium preparation to ensure a reduced milieu. Replicates of biomass-enriched sediments revealed good reproducibility (see SDs in Fig. 6). It was complicated to calculate SR rates from sulfide graphs since sulfide was removed with each medium exchange and the increase in sulfide was not consistently linear, i.e. rates changed over time. We therefore calculated rates for different time periods using 4 to 6 time points on a linear portion of sulfide accumulation curves. SR rates increased relatively steadily from 5 to $30 \mu \mathrm{mol} \mathrm{cm}^{-3} \mathrm{~d}^{-1}$ within the first $41 \mathrm{~d}$ (Fig. 6). No further rates were calculated beyond this time point because sulfide concen- trations did not increase above a level of around $19 \mathrm{mM}$. Such a high sulfide concentration possibly inhibited SR (Treude et al. 2003). The small decrease in sulfide concentrations after $69 \mathrm{~d}$ may be explained by oxygen diffusion through the rubber stopper over time. Repeated penetration of rubber stoppers with needles for subsampling could have caused slight gas permeability.

Methanogenic activity showed an immediate response to whale biomass addition in sediment slurries from $0 \mathrm{~m}$ (Fig. 6), while there was a delay of MG in slurries from 1 and $3 \mathrm{~m}$. The delay was longer $(19 \mathrm{~d})$ at $3 \mathrm{~m}$

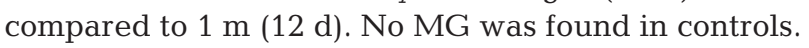
MG rates, calculated similarly to SR rates, stayed relatively steady between 4 and $8 \mu \mathrm{mol} \mathrm{cm} \mathrm{cm}^{-3} \mathrm{~d}^{-1}$ at $0 \mathrm{~m}$ (Fig. 6). At 1 and $3 \mathrm{~m}$, rates increased after the initial delay and reached similar $(1 \mathrm{~m})$ or slightly lower levels $(3 \mathrm{~m})$ relative to $0 \mathrm{~m}$. After $56 \mathrm{~d}$, methane stopped increasing in slurries from 0 and $1 \mathrm{~m}$, perhaps due to toxic sulfide levels or thermodynamically critical methane levels inhibiting MG. At $3 \mathrm{~m}$, methane concentrations increased until the end of the experiment, when they reached the maximum levels of the other distances.

At the beginning of the experiment and after $33 \mathrm{~d}$, samples for bacterial cell counts were taken from sediment slurries amended with new whale biomass. In general, microbial abundance was highest at $0 \mathrm{~m}$ followed by 1 and $3 \mathrm{~m}$. In slurries from all distances, bacterial abundance increased 2- to 3 -fold over $33 \mathrm{~d}$ (Fig. 7).

\section{Bone investigations in vitro}

Sulfate reduction rates. SR rates were highest at the bone-water interface (0 to $1 \mathrm{~cm}$ bone depth, Table 5). However, activity was very heterogeneous since 2 of 

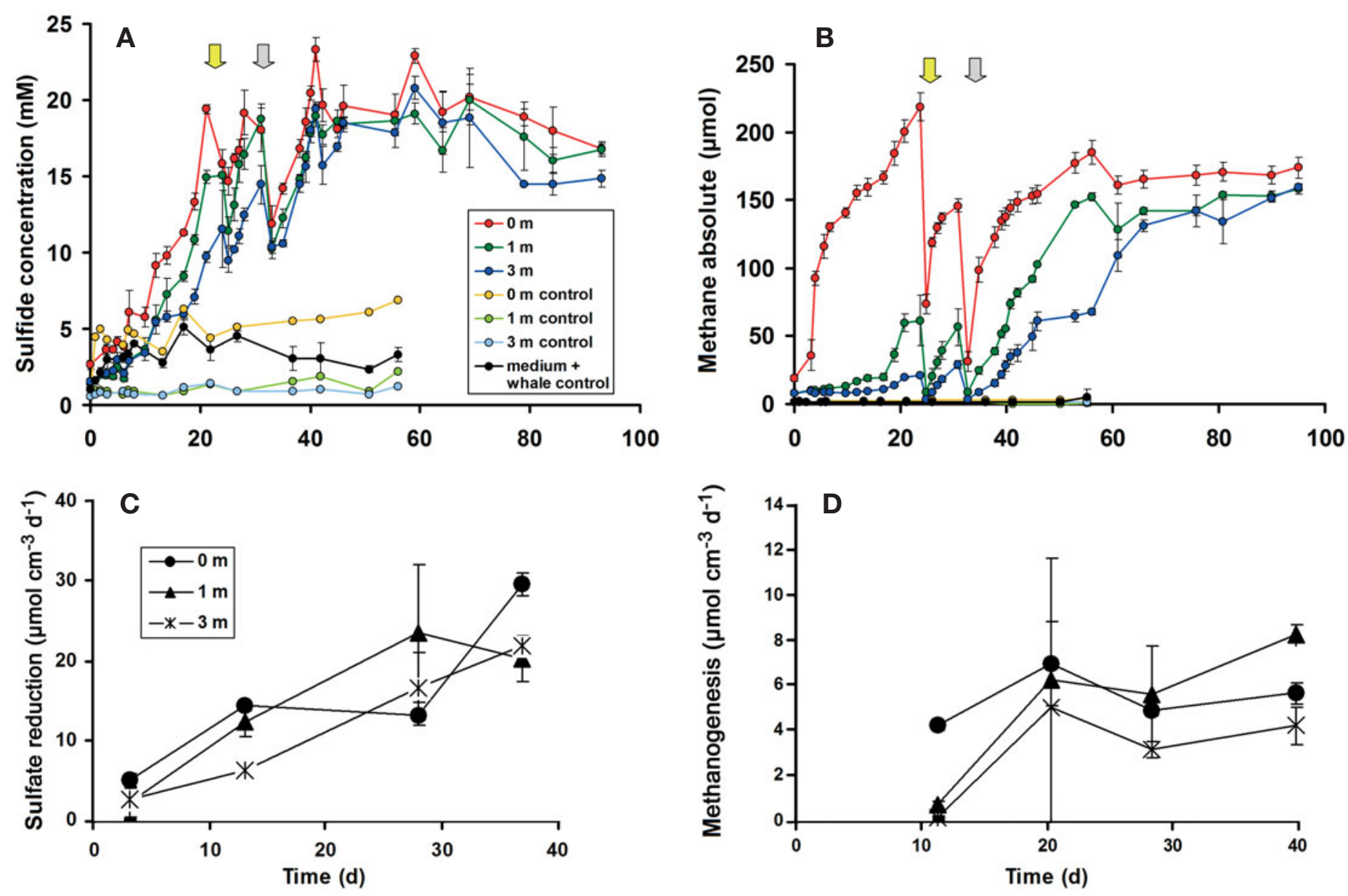

Fig. 6. (A) Sulfide and (B) methane production over time (mean \pm SD) from sediment slurries enriched with fresh whale biomass. See legend for color coding of different slurry types and controls. Yellow/gray arrows mark the time point of media exchanges. Gray arrows additionally mark the time point of subsampling for acridine orange direct counts of cell numbers. (C) Sulfate reduction (SR) and (D) methanogenesis (MG) rates over time determined for different slopes in sulfide and methane increase, respectively, from graphs above. X values are located in the middle of the respective time periods used for rate calculations (for details see 'Results, Sediment enrichment experiment')

the 4 incubated bone pieces featured no SR activity. Activity found in deeper bone layers (1 to 3 and 3 to $5 \mathrm{~cm}$ ) was very low.

Visualization of sulfide emissions. ${ }^{35} \mathrm{SO}_{4}{ }^{2-}$-radiotracer incubations of large bone pieces with silver foil also revealed SR activity mainly at the bone-water interface (Fig. 8). $\mathrm{H}_{2}{ }^{35} \mathrm{~S}$ formed a plume of silver sulfide on the silver foils, illustrating produc-

Table 5. Sulfate reduction ( $\mathrm{nmol} \mathrm{g}{ }^{-1}$ wet weight $\mathrm{d}^{-1}$ ) activity measured in whale bone pieces using ${ }^{35}$ S-radiotracer techniques

\begin{tabular}{|lcccc|}
\hline $\begin{array}{l}\text { Depth into } \\
\text { bone }(\mathrm{cm})\end{array}$ & 1 & 2 & 3 & 4 \\
\hline $0-1$ & 106 & 71 & 0 & 0 \\
$1-3$ & 0.01 & 0 & 0 & 0 \\
$3-5$ & 0.19 & 0.02 & 0 & 0 \\
\hline
\end{tabular}

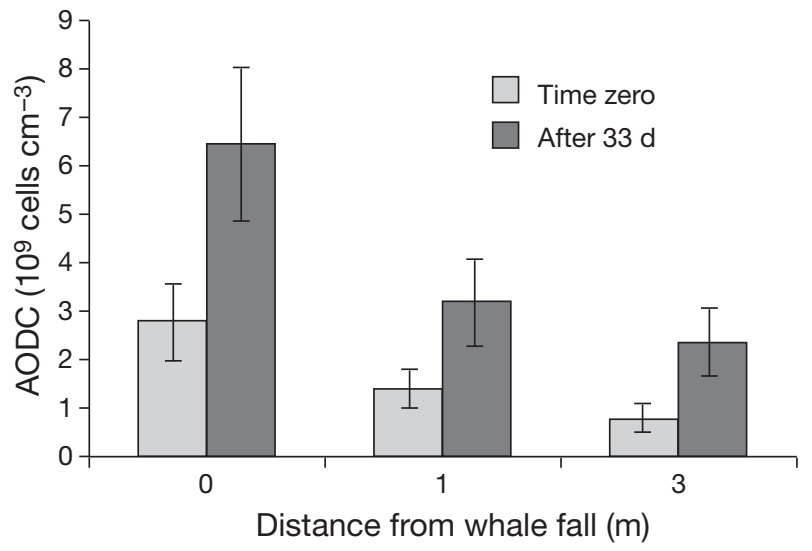

Fig. 7. Acridine orange direct counts (AODC) of microbial cells (means \pm SD) from the sediment enrichment experiment before (time zero) and $33 \mathrm{~d}$ after addition of new whale biomass. Values are calculated for the original, i.e. undiluted sediment 


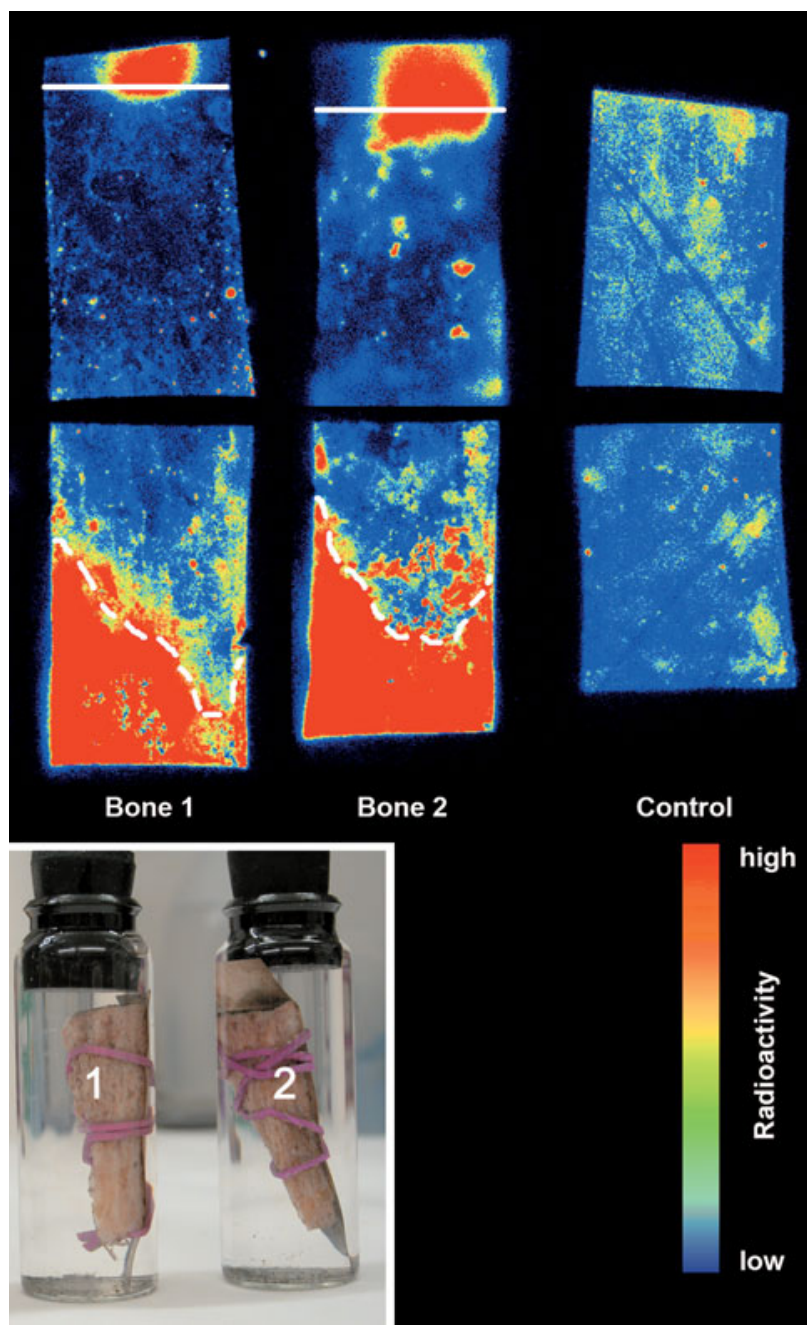

Fig. 8. (A) $\mu$-IMAGER micrographs of silver foils incubated with attached bone pieces and ${ }^{35} \mathrm{~S}$-sulfate tracer. Radioactive sulfide formed during SR reacted with the silver foil to form silver sulfide. The upper white line marks the original bone-water interface (bone below, water above) before the bone was cut. The lower dashed line marks the lower end of the cut bone; below this line the silver foil was not attached to bone. A silver foil incubated without bone served as control. (B) Incubation setup: bone pieces attached to silver foil and sealed into in glass vials with anoxic seawater medium

tion of sulfide in the bone and its emission into the water column. Small hot spots of activity were also found in deeper bone parts. The high concentration of ${ }^{35}$ S-silver sulfide on silver foil parts below the bones was remarkable. One explanation could be that oil leaking from the whale bones formed a film on the silver foil, which was then populated by sulfate reducers. Whereas sulfate was probably limiting in areas where foil was tightly sealed to the bone, the supply of sulfate was unlimited for the silver-foil biofilm.

\section{DISCUSSION}

\section{Horizontal and vertical biogeochemical gradients in sediments}

Microbial degradation of whale biomass in the sediment resulted in steep horizontal biogeochemical gradients from the background area towards the whale fall (Figs. 3 to 5, Table 4). SR and MG rates, as well as sulfide and methane concentrations, increased by several orders of magnitude within $1 \mathrm{~m}$ of the whale fall relative to more distant sediments. Organic carbon, nitrogen, sulfur and total bacterial abundance were also elevated. Electron acceptors such as sulfate and oxygen, as well as $\mathrm{pH}$, decreased rapidly with sediment depth near the whale fall. During this sulfophilic stage of the whale fall, we identified 3 sediment types impacted by whale biomass: (1) sediments covered by bacterial mats ( 0 to $0.5 \mathrm{~m}$ from the whale fall), (2) black sediment patches (0 to $0.5 \mathrm{~m}$ ) and (3) sediments inhabited by dense aggregations of tube-forming polychaetes $(\sim 0.5$ to $1 \mathrm{~m})$. Sediments investigated at 3 and $9 \mathrm{~m}$ revealed substantially lower microbial activity and no distinctive geochemical features, so they likely are more similar to background deep-sea sediments in this area. However, oxygen consumption rates were still relatively high even at $9 \mathrm{~m}(22.3 \mathrm{mmol}$ $\mathrm{m}^{-2} \mathrm{~d}^{-1}$, Table 4) compared to other basins of similar depth in this region (1 to $3 \mathrm{mmol} \mathrm{m}{ }^{-2} \mathrm{~d}^{-1}$; Smith \& Hinga 1983, Berelson et al. 1987, Fornes et al. 2001), suggesting that the whale fall affected sediment respiration rates as far as $9 \mathrm{~m}$ away even after 6 to $7 \mathrm{yr}$ at the seafloor. A similar radius of whale-fall influence was detected by Goffredi et al. (2008) in Monterey Bay.

\section{Bacterial mats vs. black sediment patches}

The 2 sediment types in the immediate vicinity of the whale fall were very similar in terms of most biogeochemical parameters. However, some interesting contrasts were noted: (1) up to $3.7 \mathrm{mM}$ sulfide was detected in sediments covered by bacterial mats (Fig. 4), while no sulfide was detected in sediments of black patches, and (2) oxygen penetration and consumption rates in black patches were not much different than in more distant (3 and $9 \mathrm{~m}$ ) sediments (Fig. 3, Table 4). These differences were surprising, given high SR rates in both patch types. Lack of sulfide-oxidizing mats on black patches suggests that free sulfide was absent at the sediment-water interface. We therefore postulate that black-patch sediments contained enough iron $\left(\mathrm{Fe}^{3+}, \mathrm{Fe}^{2+}\right)$ to completely consume free sulfide via formation of iron sulfide $(\mathrm{FeS})$ and pyrite $\left(\mathrm{FeS}_{2}\right)$ (Schippers \& Jørgensen 2002). Similar observations were recently made at cold-seep sites off New 
Zealand (S. Sommer pers. comm.), where black sediment patches were devoid of bacterial mats and sulfide despite high SR rates. In another study of coastal organic-rich sediments, chemical oxidation of sulfide with iron was found to compete with microbial oxidation (Preisler et al. 2007). We lack oxygen consumption rates and sulfide microprofiles from whale-fall sediments covered by bacterial mats since it was impossible to deploy in situ instruments in such areas due to the presence of whale bones. For comparison, cold-seep sediments covered by bacterial mats exhibited areal SR rates of 30 to $100 \mathrm{mmol} \mathrm{m}^{-2} \mathrm{~d}^{-1}$ (Treude et al. 2003) along with oxygen consumption rates in the range of 40 to $150 \mathrm{mmol} \mathrm{m}^{-2} \mathrm{~d}^{-1}$ (Sommer et al. 2006, F. Wenzhoefer unpubl. data) and sulfide concentrations as high as $26 \mathrm{mM}$ (Sahling et al. 2002). These SR rates are lower, and the sulfide concentrations higher, than we observed in whale-fall sediments covered by bacterial mats.

\section{Polychaete-inhabited sediments}

Sediments at $\sim 0.5$ to $1 \mathrm{~m}$ from the whale fall were occupied by the ampharetid polychaete Glyphanostomum sp. nov. and noticeably impacted by macrofaunal bioturbation and bioirrigation. Visually, cores could be separated into an olive-green top layer (0 to $7 \mathrm{~cm})$, a black middle layer ( 7 to $13 \mathrm{~cm}$ ) and an olive-green bottom layer $(>13 \mathrm{~cm})$. It is likely that whale biomass deposited onto sediment was buried in the middle layer ( 7 to $13 \mathrm{~cm}$ ) through bioturbation, where microbial degradation yielded reducing conditions (Allison 1988). The top layer probably remained oxidized through bioirrigation in polychaete tubes or burrows (Jørgensen et al. 2005). Methane concentrations showed a rapid increase and sulfate concentration a slight decrease below the redox interface at $7 \mathrm{~cm}$ (Fig. 4). Bioirrigation also explains stable sulfate concentrations in the top sediment layer despite SR activity (Fossing et al. 2000). However, as indicated by TOC values (Fig. 4), the total input of whale biomass to the polychaete tube area at $1 \mathrm{~m}$ must be much lower than in areas with bacterial mats and black spots, where intense reducing conditions persisted to the sediment-water interface.

In summary, rates of microbial degradation processes in deep-sea sediments enriched with whale biomass reached levels similar to or higher than organic-rich coastal sediments (e.g. TOU $=8$ to $30 \mathrm{mmol} \mathrm{m}^{-2} \mathrm{~d}^{-1}$, Glud et al. 2003; $\mathrm{SR}=\sim 0.2$ to $1.4 \mu \mathrm{mol} \mathrm{cm} \mathrm{cm}^{-3} \mathrm{~d}^{-1}$, Reeburgh 1983 and references therein). Compared to other deep-sea sediments, where sulfate concentrations may remain unchanged and methane does not build up significantly for several $10 \mathrm{~s}$ of $\mathrm{m}$ into the seafloor (D'Hondt et al. 2002, 2004), electron acceptors were consumed very rapidly at the whale fall. The concentric arrangement of biogeochemical gradients and benthic communities found around the whale fall was similar to deep-sea reducing habitats featuring confined areas of hydrocarbon seepage (e.g. mud volcanoes and gas hydrate-bearing cold seeps; Sahling et al. 2002, Treude et al. 2003, Joye et al. 2004, Niemann et al. 2006). Likewise, a hot spot of organic carbon supply locally turned energy-depleted deep-sea sediments into highly active oases for diverse aerobic and anaerobic life forms.

\section{Sulfate reduction gradients in whale bones}

Microbial sulfide production in whale vertebrae was restricted to the outermost layer $(0$ to $1 \mathrm{~cm})$, with relatively low rates compared to sediments loaded with whale biomass (Fig. 8, Table 5). Hydrophobic bone lipids filling the bone mineral matrix probably prevented a deeper penetration of seawater with dissolved sulfate, restricting the activity of sulfate-reducing bacteria (Deming et al. 1997). In contrast, lipids that leaked out of the bone appeared to be quickly colonized and degraded by sulfate-reducing bacteria (Fig. 8A). We expect that deeper penetration of SR into bones is facilitated over time by a steady degradation of lipids from the surface towards the inner core, opening pathways for seawater penetration (cf. Schuller et al. 2004). Investigations on fossil and recent (maximum of $\sim 70 \mathrm{yr}$ old) whale-fall bones revealed circular pyrite precipitates (a result of sulfide reactions with iron; Schippers \& Jørgensen 2002) several centimeters below the bone surface, indicating penetration of SR to deeper bone layers (Allison et al. 1991, Schuller et al. 2004, Amano \& Little 2005, Shapiro \& Spangler 2009). Furthermore, bacterial abundance was found to be negatively correlated with lipid content, decreasing from the periphery to the center of whale bones (Deming et al. 1997). A slow utilization of bone lipids by sulfate-reducing bacteria would explain the long persistence time (several decades) of the sulfophilic stage at southern California whale falls (Smith \& Baco 2003, Schuller et al. 2004). High concentrations of bone drilling animals, such as bone-eating worms Osedax spp., could locally facilitate faster penetration of sulfate and stimulate subsurface SR. Fossil whale-fall bones sometimes show bore holes on surfaces (Amano \& Little 2005, Shapiro \& Spangler 2009) and Osedax spp. can penetrate several millimeters into the bone matrix with its symbiont-carrying roots (Rouse et al. 2004).

\section{Co-occurrence of sulfate reduction and methano- genesis in sediments enriched with whale biomass}

This is the first comprehensive study demonstrating that both SR and MG are important microbial pro- 
cesses at deep-sea whale falls. High rates of both processes were detected in sediments around the whale fall even after 6 to $7 \mathrm{yr}$ (Figs. 4 \& 5, Table 4). Methanogens generally compete with sulfate-reducing bacteria for acetate and hydrogen (Canfield et al. 2005 and references therein). In marine sediments, a clear separation between SR and MG is often found (e.g. Niewöhner et al. 1998, Treude et al. 2005). Predominant co-occurrence of SR and MG around the whale fall in the present study suggests that the bulk of MG was based on non-competitive substrates, or that electron donors were not limiting (Holmer \& Kristensen 1994). Some methanogens are able to switch to alternative substrates such as methanol or methylamine in the presence of SR (Oremland et al. 1982). Around the whale fall, sediments were extremely enriched with whale biomass. Pieces of whale blubber and oily substances were visible in sediment cores and high TOC contents confirmed the transfer of whale biomass into the sediment. Hence, competitive and non-competitive electron donors were most likely available in excess. Similar observations were made at a whale fall in Monterey Canyon, where both $\mathrm{C}_{1}$ - and $\mathrm{H}_{2}$-utilizing methanogens were found among the microbial sediment community (Goffredi et al. 2008). In the present study, MG was equivalent to 20 to $30 \%$ of the SR (Figs. 4 \& 5, Table 4), which is surprisingly high for a deep-sea sediment. In coastal sediments, MG is usually equivalent to no more than 5 to $10 \%$ of SR (Canfield et al. 2005); only areas with extreme carbon loading such as coves or marine fish farms reach higher percentages (up to $50 \%$; Crill \& Martens 1986, Holmer \& Kristensen 1994).

The build-up of high methane levels in anoxic sediments near to the whale fall could also favor microbial breakdown of methane by anaerobic oxidation of methane (AOM) (Hinrichs \& Boetius 2002). In Monterey Canyon, methanotrophic archaea of the ANME3 group were detected $3.8 \mathrm{yr}$ after whale-fall deployment (Goffredi et al. 2008). However, in the present study, sediment slurries from 0,1 and $3 \mathrm{~m}$ from the whale fall 6 yr after deployment did not reveal AOM activity in radiotracer experiments incubated with methane $(1.4 \mathrm{mM})$ and sulfate $(28 \mathrm{mM})$ (data not shown). Either anaerobic methanotrophs are generally absent in this deep-sea area in contrast to Monterey Canyon, which hosts active seeps (Rathburn et al. 2003), or the establishment of a significant anaerobic methanotrophic community takes longer than $6 \mathrm{yr}$. Considering the heterogeneity of the sediments around the whale fall, it is also possible that hot spots of AOM were missed during our sampling. Given the high methane concentrations in sediments around the whale fall, investigation of aerobic methanotrophic bacteria at the sediment-water interface or in symbi- otic relationships with invertebrates should also be considered in future studies. So far, studies have not confirmed the presence of methanotrophic symbionts associated with whale falls (Deming et al. 1997).

During in vitro experiments mimicking the transfer of whale carcass to the seafloor through addition of fresh whale biomass to sediment slurries, a temporal succession of SR and MG was observed (Fig. 6). SR increased rapidly after new biomass addition, even in sediments collected $3 \mathrm{~m}$ from the whale fall, whereas initiation of MG showed a progressive delay with distance from the whale fall. Possibly, methanogens had to wait for the accumulation of sufficient substrates by other microorganisms before they could conduct the terminal step of biodegradation (Jørgensen 2000). Rapid response of SR in originally rather inactive sediments $(3 \mathrm{~m})$ around the whale fall indicates that in situ sulfide production probably began soon after whale biomass was buried in the sediment. Transfer of whale biomass to sediments was promoted during the mobile scavenger stage, when actively feeding megafaunal scavengers dispersed pieces of whale tissue over the seafloor (Smith \& Baco 2003). In the subsequent enrichment-opportunistic stage (18 mo after whale-fall deposition), microbial degradation of whale biomass was already indicated by high sulfide concentrations $(8 \mathrm{mM})$ in sediments adjacent to the whale fall (A. K. Hannides \& C. R. Smith unpubl. data). Hence, an overlap between enrichment-opportunistic and sulfophilic stages cannot be excluded (Smith \& Baco 2003). However, we must consider that sediments collected at $3 \mathrm{~m}$ from the whale during the present study have received whale biomass input, so that the microbial community was pre-conditioned to react quickly to biomass addition. Further experiments with reliable background sediments are needed to support our hypothesis of rapid initiation of SR by whale falls.

\section{Sulfide availability}

In order to estimate sulfide availability for chemosynthetic communities at the whale fall, both SR in bones and in the sediment must be considered.

\section{Sediments}

The most productive sediment area was found within $0.5 \mathrm{~m}$ of the whale fall. Here, dense mats of filamentous, sulfide-oxidizing bacteria and black patches were observed. We extrapolated averaged areal SR rates in sediment cores from bacterial mats and black patch areas (Table 4 ) to the total area of each habitat estimated from the photomosaics in 2004 and 2005 
(Table 3). We then calculated total sediment sulfide production in the 0.5 radius, revealing $2.1 \pm 3.0 \mathrm{~mol} \mathrm{~d}^{-1}$ in 2004 and $1.5 \pm 2.1 \mathrm{~mol} \mathrm{~d}^{-1}$ in 2005 (SDs originate from variations in areal rates, see Table 4). In black patches, none of the sulfide produced was likely available for the chemoautotrophic community, due to its chemical consumption (see above). For bacterial mats it was difficult to estimate the amount of free sulfide available, since we did not know how much sulfide was consumed abiotically. In deep-sea cold-seep sediments covered by bacterial mats, oxygen and nitrate consumption rates were 47.5 and $4.6 \mathrm{mmol} \mathrm{m} \mathrm{m}^{-2} \mathrm{~d}^{-1}$, respectively (Sommer et al. 2006), while SR rates related to anaerobic oxidation of methane ranged between 30 and $100 \mathrm{mmol} \mathrm{m}^{-2} \mathrm{~d}^{-1}$ (Treude et al. 2003). In the cold-seep case, we can assume that at least $25 \%$ of the sulfide produced was consumed by sulfide-oxidizing bacteria using oxygen and nitrate $\left(2 \mathrm{O}_{2}\right.$ and $4 \mathrm{NO}_{3}{ }^{-}$for $1 \mathrm{H}_{2} \mathrm{~S}$, respectively; Jørgensen \& Nelson 2004), while the rest precipitated in the sediments. Applying this number to the present study, we suggest that on average $\sim 200 \mathrm{mmol} \mathrm{d}^{-1}$ of free sulfide was available in sediments covered by bacterial mats. Differences between 2004 and 2005 (218 vs. 205 mmol) were minimal.

\section{Bones}

Sulfide availability in bones was much more difficult to estimate because bone surface areas were unknown. Furthermore, SR rates were measured in only one vertebra and activity seemed to be patchy (Table 5). As a starting point, we assumed that SR rates measured in bone pieces represented the total activity below $1 \mathrm{~cm}^{2}$ of bone surface area (this was the approximate surface area cut from the bone per sample). Furthermore, we assumed that bone pieces featuring SR activity (71 and $106 \mathrm{nmol} \mathrm{g}$ wet weight $\mathrm{d}^{-1}$, mean $=89 \mathrm{nmol} \mathrm{g}$ wet weight $\mathrm{d}^{-1}$ ) were originally covered by sulfide-oxidizing bacterial mats, whereas pieces with no activity were mat-free. The percentage of bone surface with active SR was then assumed to be the percentage of visible bones covered by bacterial mats estimated from photographs in 2004 and 2005 (Table 2). The most difficult part was the estimation of bone surface areas. Since surfaces could not be determined at the deployed grey whale skeleton (body length $=12.5 \mathrm{~m}$ ), we estimated the surface area of the skeleton of an available baleen whale with the closest body length compared to our whale fall: a skeleton of a $17.6 \mathrm{~m}$ blue whale Balaenoptera musculus at the Natural History Museum of Los Angeles, CA. We measured the dimensions of vertebrae, ribs, scapulae, mandibles and the skull (including maxillae), applied simple geometric shape models (e.g. an ellipsoid cylindrical shape for the central disk of the vertebra and rectangular shapes for the processes) and then calculated bone surface areas. We estimated a total skeleton surface of $82 \mathrm{~m}^{2}$ for the blue whale (not including pectoral fin bones) (Table 6). This conservative approach underestimated the actual bone surface area because we could not account for cavities, fissures and other irregularities in bone surfaces. From our whale-fall pictures taken in 2005, we roughly estimated that about two-thirds of the bone surface area was visible above the seafloor, i.e. was unburied. In order to obtain the total skeleton area producing sulfide at our whale fall, we used the following equation:

Whale-fall bone area producing sulfide $=$

$$
B M_{\mathrm{cov}} \frac{2}{3}+A_{\mathrm{bwb}} \frac{L_{\mathrm{gw}}{ }^{2}}{L_{\mathrm{bw}}{ }^{2}}
$$

where $B M_{\text {cov }}$ is the proportion of visible bone surface covered by bacterial mats, $2 / 3$ is the proportion of total bone surface area visible (i.e. unburied), $A_{\mathrm{bwb}}$ is the total surface area of the respective bone type of the blue whale $\left(\mathrm{cm}^{2}\right), L_{\mathrm{gw}}$ is the length of the grey whale (m) and $L_{\mathrm{bw}}$ is the length of the blue whale (m) (for values see also Tables $2 \& 6$ ). The sulfide-producing area was then multiplied by an average production rate of

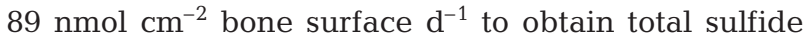
production rates of visible bone surfaces. Thus, we calculated that a total of $\sim 10 \mathrm{mmol}$ sulfide was produced per day over an active whale-bone area of roughly $12 \mathrm{~m}^{2}$ (Table 6). Since there was probably little abiotic consumption of sulfide in the bones, we assume that a similar amount of free sulfide was likely available for chemosynthesis. This calculation is very rough and most likely underestimates the total sulfide production from bones. Comparing the whale skeleton with the surrounding sediment ( $0.5 \mathrm{~m}$ radius), total availability of sulfide was approximately one order of magnitude lower on the bones. This ratio likely changed over the years in favor of the bones, since we can assume that

Table 6. Sulfide production rates calculated for visible parts of the whale-fall bones. Coverage of bacterial mat was used as an indicator of sulfide production activity in bones. For area calculation, see Eq. (1)

\begin{tabular}{|c|c|c|c|c|}
\hline $\begin{array}{l}\text { Bone } \\
\text { type }\end{array}$ & $\begin{array}{c}\text { Reference } \\
\text { area } \\
\left(\mathrm{m}^{2}\right)\end{array}$ & $\begin{array}{c}\text { Area } \\
\text { by bac } \\
(\%)\end{array}$ & $\begin{array}{l}\text { vered } \\
\text { ial mat } \\
\left(\mathrm{m}^{2}\right)\end{array}$ & $\begin{array}{c}\text { Sulfide } \\
\text { production } \\
\left(\mathrm{mmol} \mathrm{d}^{-1}\right)\end{array}$ \\
\hline Vertebra & 38.7 & 34 & 6.64 & 5.9 \\
\hline Skull & 15.6 & 63 & 4.93 & 4.4 \\
\hline Mandible & 7.36 & 30 & 1.11 & 1.0 \\
\hline Scapula & 0.97 & 40 & 0.20 & 0.2 \\
\hline Ribs & 19 & 51 & 4.86 & 4.3 \\
\hline Total & 54.3 & & 11.57 & 10.3 \\
\hline
\end{tabular}


biomass in the sediments is consumed faster than in bones (see Smith et al. 1998). In bones, fatty lipids are probably degraded slowly from outside to inside, and the space for microbial growth is limited, whereas in sediments microbial abundance can be much higher, and bioturbation and bioirrigation are likely to accelerate microbial degradation processes.

\section{Total sulfide and methane production}

Assuming that whale biomass has a dry weight content of $40 \%$, consisting of $20 \%$ protein and $20 \%$ fat, of which 54 and $77 \%$, respectively, represent carbon (Jelmert \& Oppen-Berntsen 1996), our 30 t grey whale had a total carbon content of roughly $3 \mathrm{t}$. If we assume average sediment rates of $\mathrm{SR}$ and $\mathrm{MG}$ of $\sim 2$ and $\sim 0.5 \mathrm{~mol} \mathrm{~d}^{-1}$ (25\% of $\mathrm{SR}$, see above), respectively, roughly $5.1 \mathrm{kmol}$ sulfide and $1.3 \mathrm{kmol}$ methane were produced over the $7 \mathrm{yr}$. In the skeleton, the amount of sulfide produced would account for roughly $31 \mathrm{~mol}$. For sediments, these numbers are most likely underestimates, since organic carbon content, and hence microbial degradation rates, were probably higher during earlier stages of the whale fall. According to the stoichiometry of SR, the amount of sulfate reduced should be multiplied by 2 to convert it into carbon equivalents (Kallmeyer et al. 2004). Depending on the substrate $\left(\mathrm{C}_{1}\right.$ or $\mathrm{C}_{2}$ compounds), MG should be multiplied by 1 or 2 , respectively, for the conversion into carbon equivalents (Thauer 1998); in the present calculation we multiplied by 1.5 since the percentage of utilized $\mathrm{C}_{1}$ and $\mathrm{C}_{2}$ substrates was unknown. These conversions suggest that at least $122 \mathrm{~kg} \mathrm{(4 \% )} \mathrm{and}$ $23 \mathrm{~kg}(0.8 \%)$ of the whale carbon were consumed by $\mathrm{SR}$ and MG in the sediments, respectively, and $0.7 \mathrm{~kg}$ $(0.3 \%)$ by $\mathrm{SR}$ in the bones within the first $7 \mathrm{yr}$. We assume that large amounts of degradable whale carbon were still available after $7 \mathrm{yr}$ in both sediments and bones, since large pieces of whale blubber and oil were found in sediments, and bone lipids had been depleted only on the periphery. Estimated lipid con- sumption rates by sulfate roughly match lipid loss rates estimated for well-calcified whale bones at the deepsea floor by Schuller et al. (2004), and suggest that the sulfophilic stage can persist for substantially longer than 7 yr on this whale fall.

\section{Comparison with other sulfur-based habitats}

Whale falls create sulfide-rich habitats analogous to hydrothermal vent or cold-seep systems (Smith et al. 1989, Smith \& Baco 2003). Today, at least 11 species found on whale falls are known also from hydrothermal vents, as well as at least 20 species from cold seeps (Smith \& Baco 2003, Smith 2006). Overlap in communities and similarities in sulfur-based food-webs led to the stepping stone hypothesis that whale falls may serve as intermediate habitats for the dispersal of some hydrothermal vent and cold-seep species (Smith et al. 1989). Here, we compare the 3 habitat types on the basis of biogeochemical parameters to see whether organisms using sulfide as energy source may encounter similar conditions (Table 7). Areal SR rates, as well as sulfide concentrations, in whale-fall sediments were similar to cold-seep environments such as Hydrate Ridge or the Gulf of Mexico seeps (Treude et al. 2003, Joye et al. 2004) (Table 7), suggesting that these habitats provide qualitatively analogous conditions for these variables. Only some cold-seep areas with extremely high methane fluxes reach higher sulfide levels (max. 26 mM, Sahling et al. 2002) (Table 7). However, individual whale falls are small in areal extent and short-lived (lasting for decades vs. 100 to $1000 \mathrm{yr}$ ) for some cold seeps (Fisher et al. 1997, Hornafius et al. 1999, Schuller et al. 2004) (Table 7). The skeletons of whale falls, with apparently low and heterogeneous SR rates associated with hard substrates, might be more similar to hydrothermal vent systems, where sulfide concentrations in the surrounding water reach relatively low levels $(<0.1$ to $1 \mathrm{mM})$-due to rapid dilution-and are often patchy (Johnson et al. 1986, Luther et al. 2001) (Table 7). Also, the presence

Table 7. Comparisons of environmental parameters (i.e. sulfate reduction, sulfide concentration, active area emitting sulfide and persistence time of sulfide emission) at whale falls, cold seeps and hydrothermal vents

\begin{tabular}{|c|c|c|c|c|}
\hline $\begin{array}{l}\text { Chemosynthetic } \\
\text { habitat }\end{array}$ & $\begin{array}{l}\text { Max. sulfate reduction } \\
\quad\left(\mathrm{mmol} \mathrm{m}^{-2} \mathrm{~d}^{-1}\right)\end{array}$ & $\begin{array}{l}\text { Max. free sulfide } \\
\text { concentration }(\mathrm{mM})\end{array}$ & $\begin{array}{c}\text { Total active area } \\
\left(\mathrm{m}^{2}\right)\end{array}$ & $\begin{array}{l}\text { Persistence time } \\
\text { (yr) }\end{array}$ \\
\hline Whale falls & $\begin{array}{c}\text { Bones: } \sim 1^{\mathrm{a}} \\
\text { Sediments: } 400-700^{\mathrm{a}}\end{array}$ & Sediments: $1-8^{\mathrm{a}, \mathrm{d}}$ & $\begin{array}{c}\text { Bones: } \sim 12^{\mathrm{a}} \\
\text { Sediments: } 2-3^{\mathrm{a}}\end{array}$ & $10-80^{\mathrm{i}}$ \\
\hline Cold seeps & $32-250^{\mathrm{b}, \mathrm{c}}$ & $1-26^{\mathrm{c}, \mathrm{e}}$ & $\leq 18 \times 10^{6 \mathrm{~h}}$ & Probably 100 s to $1000 s^{j}$ \\
\hline Hydrothermal vents & - & $<0.1-1^{\mathrm{f}, \mathrm{g}}$ & Restricted to chimneys & Probably decades ${ }^{\mathrm{k}}$ \\
\hline
\end{tabular}


of rocky surfaces, restricted spatial extent and relatively short persistence times of some hydrothermal systems seem to be more similar to whale skeletons (Van Dover 2000). In summary, whale falls offer a broad range of habitat conditions for sulfophilic communities with similarities to both cold seeps and hydrothermal vents, but in terms of persistence time and habitat whale falls are more similar to hydrothermal systems.

\section{CONCLUSIONS}

We found that a $30 \mathrm{t}$ gray whale carcass can create a chemosynthetic habitat both in sediments and on bone surfaces for more than $7 \mathrm{yr}$. Dominant biogeochemical processes supporting the development of a chemosynthetic community were microbial SR (in sediments and bones) and MG (in sediments), accounting for at least $5 \%$ of total carbon input from the whale fall. Excess availability of substrates most likely eliminated competition between sulfate-reducing and methanogenic communities in sediments. Changes in areas of bacterial mats and black sediment patches between 2004 and 2005 suggest that the whale-fall based reducing habitat is only slowly declining 7 yr after carcass arrival at the seafloor. The whale fall created a sedimentary reducing habitat similar to deep-sea cold seeps in terms of sulfide production, but is temporally and spatially much more restricted than many seeps. Bones, on the other hand, provided sustained, low emissions of sulfide probably more similar to hydrothermal vent systems. Quick response of the microbial community to whale biomass addition, even in formerly rather inactive sediments from around the whale fall, indicates that the sulfophilic stage of whale-fall succession could become established rapidly, i.e. during the enrichmentopportunist stage, after whale biomass is dispersed over the seafloor by feeding activity of scavengers. Precise estimation of the temporal succession of sulfophilic communities requires further investigations with sediments far removed from the influence of whale falls.

Acknowledgements. We thank the crew and shipboard scientific party of the RV 'Western Flyer' as well as the crew of the ROV 'Tiburon' for excellent support during the 2 expeditions. We particularly thank S. Mincks, S. Wigley, S. Menger, I. Busse, M. Alisch, A. Rohwedder, M. Kohn, V. Beier and R. Appel for technical support in the laboratory. G. Eickert is thanked for microsensor manufacture, and M. Viehweger, A. Nordhausen, V. Meyer and P. Färber for construction of the in situ equipment. Help with photomosaicking came from FIELAX (I. Suck). Whale biomass for the in vitro enrichment experiment was provided by U. Siebert, Forschungs- und Technologiezentrum Westküste, Germany. The blue whale skeleton was made available by J. Dines from the Natural History Museum, Los Angeles, and we thank S. Böhme for his help with the blue whale bone measurements. Support for the summer project of E.C. came from the Max Planck Society (Munich, Germany) and the Research Center Ocean Margins (Bremen, Germany). A.F.B. was partially supported by CAPES and CNPq (Brazil) and by the Census of Diversity of Abyssal Marine Life. This work was funded by grants from the National Undersea Research Center Alaska, NOAA (now the West Coast and Polar Regions Undersea Research Center), and the USA National Science Foundation, Biological Oceanography Program (grant OCE 0096422) to C.R.S. This work further contributed to the European project EXOCET/D. Additional support came from the Max Planck Society, the University of Hawaii at Manoa and the Monterey Bay Aquarium Research Institute. This is contribution no. 7748 from the School of Ocean and Earth Science and Technology, University of Hawaii at Manoa. We also thank 3 anonymous reviewers for their helpful comments on the manuscript.

\section{LITERATURE CITED}

Allison PA (1988) The role of anoxia in the decay and mineralization of proteinaceous macro-fossils. Paleobiology 14:139-154

Allison PA, Smith CR, Kukert H, Deming JW, Bennett BA (1991) Deep-water taphonomy of vertebrate carcasses: a whale skeleton in the bathyal Santa Catalina Basin. Paleobiology 17:78-89

Amano K, Little CTS (2005) Miocene whale-fall community from Hokkaido, northern Japan. Palaeogeogr Palaeoclimatol Palaeoecol 215:345-356

$>$ Baco AR, Smith CR (2003) High species richness in deep-sea chemoautotrophic whale skeleton communities. Mar Ecol Prog Ser 260:109-114

Baco AR, Smith CR, Peek AS, Roderick GH, Vrijenhoek RC (1999) The phylogenetic relationships of whale-fall vesicomyid clams based on mitochondrial COI DNA sequences. Mar Ecol Prog Ser 182:137-147

> Bennett BA, Smith CR, Glaser B, Maybaum HL (1994) Faunal community structure of a chemoautotrophic assemblage on whale bones in the deep northeast Pacific Ocean. Mar Ecol Prog Ser 108:205-223

Berelson WD, Hammond DE, Smith KL, Jahnke RA and others (1987) In situ benthic flux measurement devices: bottom lander technology. Mar Technol Soc J 21:26-32

Boetius A, Lochte K (1996) Effect of organic enrichments on hydrolytic potentials and growth of bacteria in deep-sea sediments. Mar Ecol Prog Ser 140:239-250

Canfield DE, Thamdrup B, Kristensen E (2005) Aquatic geomicrobiology, Vol 48. Elsevier, San Diego, CA

Cline JD (1969) Spectrophometric determination of hydrogen sulfide in natural waters. Limnol Oceanogr 14:454-458

Cord-Ruwisch R (1985) A quick method for the determination of dissolved and precipitated sulfides in cultures of sulfate-reducing bacteria. J Microbiol Methods 4:33-36

Crill PM, Martens CM (1986) Methane production from bicarbonate and acetate in an anoxic marine sediment. Geochim Cosmochim Acta 50:2089-2097

D'Hondt S, Rutherford S, Spivack AJ (2002) Metabolic activity of subsurface life in deep-sea sediments. Science 295: $2067-2070$

D'Hondt S, Jørgensen BB, Miller DJ, Batzke A and others (2004) Distribution of microbial activities in deep subseafloor sediments. Science 306:2216-2221

> Deming JW, Reysenbach AL, Macko SA, Smith CR (1997) Evidence for the microbial basis of a chemoautotrophic invertebrate community at a whale fall on the deep sea- 
floor: bone-colonizing bacteria and invertebrate endosymbionts. Microsc Res Tech 37:162-170

Feldman RA, Shank TM, Black MB, Baco AR, Smith CR, Vrijenhoek RC (1998) Vestimentiferan on a whale fall. Biol Bull 194:116-119

Fisher CR, Urcuyo IA, Simpkins MA, Nix E (1997) Life in the slow lane: growth and longevity of cold-seep vestimentiferans. PSZNI: Mar Ecol 18:83-94

Fornes WL, DeMaster DJ, Smith CR (2001) A particle introduction experiment in Santa Catalina Basin sediments: testing the age-dependent mixing hypothesis. J Mar Res 59:97-112

Fossing H, Ferdelman TG, Berg P (2000) Sulphate reduction and methane oxidation in continental sediments influenced by irrigation (South-East Atlantic off Namibia). Geochim Cosmochim Acta 64:897-910

Glud RN, Gundersen JK, Ramsing NB (2000) Electrochemical and optical oxygen microsensors for in situ measurements. In: Buffle J, Horvai G (eds) In situ monitoring of aquatic systems: chemical analysis and speciation. Wiley, Chichester, p 19-73

Glud RN, Gundersen JK, Jørgensen BB (2003) Seasonal dynamics of benthic $\mathrm{O}_{2}$ uptake in a semienclosed bay: importance of diffusion and faunal activity. Limnol Oceanogr 48:1265-1276

Goffredi SK, Wilpiszeski R, Lee R, Orphan V (2008) Temporal evolution of methane cyling and phylogenetic diversity of archaea in sediments from a deep-sea whale-fall in Monterey Canyon, California. ISME J 2:204-220

> Gundersen JK, Jørgensen BB (1990) Microstructure of diffusive boundary layers and the oxygen uptake of the sea floor. Nature 345:604-607

Hinrichs KU, Boetius A (2002) The anaerobic oxidation of methane: new insights in microbial ecology and biogeochemistry. In: Wefer G, Billett D, Hebbeln D, Joergensen $\mathrm{BB}$, Schlüter $\mathrm{M}$, Van Weering $\mathrm{T}$ (eds) Ocean margin systems. Springer-Verlag, Berlin, p 457-477

- Holmer M, Kristensen E (1994) Coexistence of sulfate reduction and methane production in an organic-rich sediment. Mar Ecol Prog Ser 107:177-184

Hornafius JS, Quigley D, Luyendyk BP (1999) The world's most spectacular marine hydrocarbon seeps (Coal Oil Point, Santa Barbara Channel, California): quantification of emissions. J Geophys Res 104:20703-20711

Jelmert A, Oppen-Berntsen DO (1996) Whaling and deep-sea biodiversity. Conserv Biol 10:653-654

> Jeroschewski P, Steuckart C, Kühl M (1996) An amperometric microsensor for the determination of $\mathrm{H}_{2} \mathrm{~S}$ in aquatic environments. Anal Chem 68:4351-4357

Johnson KS, Beehler CL, Sakamoto-Arnold CM, Childress JJ (1986) In situ measurements of chemical distributions in a deep-sea hydrothermal vent field. Science 231:1139-1141

Jørgensen BB (1978) A comparison of methods for the quantification of bacterial sulphate reduction in coastal marine sediments: I. Measurements with radiotracer techniques. Geomicrobiol J 1:11-27

Jørgensen BB (2000) Bacteria and marine biogeochemistry. In: Schulz HD, Zabel M (eds) Marine biogeochemistry. Springer-Verlag, Berlin, p 173-201

Jørgensen BB, Nelson DC (2004) Sulfide oxidation in marine sediments: geochemistry meets microbiology. Geol Soc Am Spec Pap 379:63-81

Jørgensen BB, Revsbech NP (1985) Diffusive boundary layers and the oxygen uptake of sediments and detritus. Limnol Oceanogr 30:111-122

Jørgensen BB, Glud RN, Holby O (2005) Oxygen distribution and bioirrigation in Arctic fjord sediments (Svalbard, Barents Sea). Mar Ecol Prog Ser 292:85-95
Joye SB, Boetius A, Orcutt BN, Montoya JP, Schulz HN, Erickson MJ, Logo SK (2004) The anaerobic oxidation of methane and sulfate reduction in sediments from Gulf of Mexico cold seeps. Chem Geol 205:219-238

Kallmeyer J, Ferdelman TG, Weber A, Fossing H, Jørgensen BB (2004) A cold chromium distillation procedure for radiolabeled sulfide applied to sulfate reduction measurements. Limnol Oceanogr Methods 2:171-180

Krüger M, Frenzel P, Conrad R (2001) Microbial processes influencing methane emission from rice fields. Glob Change Biol 7:49-61

Lanièce P, Charon Y, Cardona A, Pinot L and others (1998) A new high resolution radioimager for quantitative analysis of radiolabelled molecules in tissue section. J Neurosci Methods 86:1-5

Luther GW III, Rozan TF, Taillefert M, Nuzzio DB and others (2001) Chemical speciation drives hydrothermal vent ecology. Nature 410:813-816

Meyer-Reil LA (1983) Benthic response to sedimentation events during autumn to spring at a shallow water station in the western Kiel Bight. Mar Biol 77:247-256

- Naganuma T, Wada H, Fujioka K (1996) Biological community and sediment fatty acids associated with the deep-sea whale skeleton at the Torishima Seamount. J Oceanogr 52:1-15

Nauhaus K, Boetius A, Krüger M, Widdel F (2002) In vitro demonstration of anaerobic oxidation of methane coupled to sulphate reduction in sediment from marine gas hydrate area. Environ Microbiol 4:296-305

Niemann H, Lösekann T, De Beer D, Elvert $M$ and others (2006) Novel microbial communities of the Haakon Mosby mud volcano and their role as a methane sink. Nature 443:854-858

> Niewöhner C, Hensen C, Kasten S, Zabel M, Schulz HD (1998) Deep sulfate reduction completely mediated by anaerobic methane oxidation in sediments of the upwelling area off Namibia. Geochim Cosmochim Acta 62: $455-464$

> Oremland RS, Marsh LM, Polcin S (1982) Methane production and simultaneous sulphate reduction in anoxic, salt marsh sediments. Nature 296:143-145

Preisler A, De Beer D, Lichtschlag A, Lavik G, Boetius A, Jørgensen BB (2007) Biological and chemical sulfide oxidation in a Beggiatoa inhabited marine sediment. ISME J $1: 341-353$

Rasmussen H, Jørgensen BB (1992) Microelectrode studies of seasonal oxygen uptake in a coastal sediment: role of molecular diffusion. Mar Ecol Prog Ser 81: 289-303

Rathburn AE, Pérez ME, Martin JB, Day SA and others (2003) Relationships between the distribution and stable isotopic composition of living benthic foraminifera and cold methane seep biogeochemistry in Monterey Bay, California. Geochem Geophys Geosyst 4:1106

> Reeburgh WS (1983) Rates of biogeochemical processes in anoxic sediments. Annu Rev Earth Planet Sci 11:269-298

> Reimers CE, Ruttenberg KC, Canfield DE, Christiansen MB, Martin JB (1996) Porewater pH and authigenic phases formed in the uppermost sediments of Santa Barbara Basin. Geochim Cosmochim Acta 60:4037-4057

Revsbech NP (1989) An oxygen microelectrode with a guard cathode. Limnol Oceanogr 34:474-478

Revsbech NP, Jørgensen BB (1986) Microelectrodes: their use in microbial ecology. Adv Microb Ecol 9:293-352

Rouse GW, Goffredi SK, Vrijenhoek RC (2004) Osedax: boneeating marine worms with dwarf males. Science 305: 668-671 
Sahling H, Rickert D, Raymond WL, Linke P, Suess E (2002) Macrofaunal community structure and sulfide flux at gas hydrate deposits from the Cascadia convergent margin, NE Pacific. Mar Ecol Prog Ser 231:121-138

Schippers A, Jørgensen BB (2002) Biogeochemistry of pyrite an iron sulfide oxidation in marine sediments. Geochim Cosmochim Acta 66:85-92

Schuller D, Kadko D, Smith CR (2004) Use of ${ }^{210} \mathrm{~Pb} /{ }^{226}$ Ra disequilibria in the dating of deep-sea whale falls. Earth Planet Sci Lett 218:277-289

Shapiro RS, Spangler E (2009) Bacterial fossil record in whalefalls: petrographic evidence of microbial sulfate reduction. Palaeogeogr Palaeclimatol Palaeoecol 274:196-203

Smith CR (1992) Whale falls: chemosynthesis on the deep-sea floor. Oceanus 36:74-78

Smith CR (2006) Bigger is better: the role of whales as detritus in marine ecosystems. In: Estes J, DeMaster DP, Doak DF, Williams TM, Brownell RL Jr (eds) Whales, whaling and ocean ecosystems. California University Press, Berkeley, CA, p 286-302

Smith CR, Baco AR (2003) Ecology of whale falls at the deepsea floor. Oceanogr Mar Biol Annu Rev 41:311-354

Smith CR, Kukert H, Wheatcroft RA, Jumars PA, Deming JW (1989) Vent fauna on whale remains. Nature 34:127-128

Smith CR, Maybaum HL, Baco AR, Pope RH and others (1998) Sediment community structure around a whale skeleton in the deep Northeast Pacific: macrofaunal, microbial and bioturbation effects. Deep-Sea Res II 45:335-364

Smith CR, Baco AR, Glover A (2002) Faunal succession on replicate deep-sea whale falls: time scales and vent-seep affinities. Cah Biol Mar 43:293-297

Smith KL, Hinga KR (1983) Sediment community respiration in the deep sea. In: Rowe GT (ed) Deep-sea biology, Vol 8. John Wiley \& Sons, New York

Editorial responsibility: Matthias Seaman, Oldendorf/Luhe, Germany
Soetaert K, Hofmann AF, Middelburg JJ, Meysman FJR, Greenwood J (2007) The effect of biogeochemical processes on $\mathrm{pH}$. Mar Chem 105:30-51

> Sommer S, Pfannkuche O, Linke P, Luff R and others (2006) Efficiency of the benthic filter: biological control of the emission of dissolved methane from sediments containing shallow gas hydrates at Hydrate Ridge. Global Biogeochem Cycles 20:GB2019

Thauer RK (1998) Biochemistry of methanogenesis: a tribute to Marjory Stephenson. Microbiology 144:2377-2406

Treude T, Boetius A, Knittel K, Wallmann K, Jørgensen BB (2003) Anaerobic oxidation of methane above gas hydrates at Hydrate Ridge, NE Pacific Ocean. Mar Ecol Prog Ser 264:1-14

Treude T, Niggemann J, Kallmeyer J, Wintersteller P, Schubert CJ, Boetius A, Jørgensen BB (2005) Anaerobic oxidation of methane in the sulfate-methane transition along the Chilean continental margin. Geochim Cosmochim Acta 69:2767-2779

Van Dover CL (2000) The ecology of deep-sea hydrothermal vents. Princeton University Press, Princeton, NJ

> Wenzhöfer F, Holby O, Glud RN, Nielsen HK, Gundersen JK (2000) In situ microsensor studies of a shallow water hydrothermal vent at Milos, Greece. Mar Chem 69:43-54

> Wenzhöfer F, Glud RN (2002) Benthic carbon mineralization in the Atlantik: a synthesis based on in situ data from the last decade. Deep-Sea Res I 49:1255-1279

Widdel F, Bak F (1992) Gram-negative mesophilic sulfatereducing bacteria. In: Balows $A$, Trüper HG, Dworking $M$, Harder W, Schleifer KH (eds) The prokaryotes. Springer, New York, p 3352-3378

Yamamoto S, Alcauskas JB, Crozier TE (1976) Solubility of methane in distilled water and seawater. J Chem Eng Data 21:78-80

Submitted: May 13, 2008; Accepted: February 11, 2009 Proofs received from author(s): April 27, 2009 